\title{
THE PAIN AND SUFFERING OF ENVIRONMENTAL LOSS: USING CONTINGENT VALUATION TO ESTIMATE NONUSE DAMAGES
}

\author{
JEFFREY C. DOBBINS
}

There will always be controversy where intangible losses have to be evaluated in monetary terms. ${ }^{1}$

\section{INTRODUCTION}

In the summer of 1987, the last known dusky seaside sparrow died in captivity in Florida. ${ }^{2}$ Despite the permanence of this loss, it probably had no effect on our individual standards of living. The dusky seaside sparrow was not sold on the market and was not a source of decorative feathers nor of any other resource. Most of us have never even seen a dusky seaside sparrow. In terms of market value, at least, its loss appears to have been costless.

Our society, however, recognizes that market value alone does not fully capture the injury that occurs when species are driven to extinction. The Endangered Species Act (ESA), for example, imposes a complete ban on activities that threaten the well-being of

Copyright (0) 1994, Jeffrey C. Dobbins.

1. Report of the National Oceanic and Atmospheric Administration (NOAA) Panel on Contingent Valuation, 58 Fed. Reg. 4601, 4611 (1993) [hereinafter NOAA Panel Report]. The Panel was established to "evaluate the use of [contingent valuation] in determining nonuse values and provide comments to NOAA." Id. at 4602. The Panel members were Kenneth Arrow and Robert Solow (co-chairs), Edward Leamer, Paul Portney, Roy Randner, and Howard Schuman. Id.

2. For a history of the demise of the species, see Barry Bearak, Three Duskies Remain: Tiny Birds Soon to Sing Swan Songs, L.A. TMES, Jan. 3, 1985, § 1, at 1 (linking the passing of the species to habitat loss caused by development and discussing the last three birds, all male, that had been moved into a captive back-breeding program in an effort to recover a population); Kerry Gruson, Effort to Save a Species: Brief Cheer, Then Gloom, N.Y. TMES, Oct. 7, 1985, at A23 (describing the remaining two birds and the poor success of the back-breeding program); John N. Wilford, Last Dusky Sparrow Struggles On, N.Y. TiMES, Apr. 29, 1986, at C1; Last of Dusky Sparrows Dies, N.Y. TIMES, July 17, 1987, at A20. 
endangered species, even when doing so results in significant economic losses. ${ }^{3}$ That ban is a pohtical and legal reflection ${ }^{4}$ of the feehings of nrany people in the United States and throughout the world who value the inere existence of a species and suffer a deep sense of regret at its passing. Whether this emotion stenus from a semi-spiritual connection that individuals feel with other species, from a sense that the way we treat other species is representative of our ability to respect each other, or from a sense that those species deserve respect merely because they, too, are alive, ${ }^{5}$ this "existence value" is an important part of the total value ${ }^{6}$ that our natural resources provide to the nation. ${ }^{7}$ But the existence value

3. 16 U.S.C. $\$ \S 1531-44$ (1988 \& Supp. IV 1992). On rare occasions when potential economic losses are particularly large, the Endangered Species Committee may be called into action to determine whether those losses are truly justified in the name of saving the species. See id. $\S 1536($ e). If not, the Committee can grant an exemption, even if to do so leads to the extinction of the species. See id. $\S 1536(\mathrm{e})(2)$. Thus, although we place an extremely high value on the protection of endangered species, it is not infinitely high. The recent debates in the Pacific Northwest over the spotted owl have provided one case in which the economic (and political) costs have whittled away at the Act's near-absolute commitment to species survival. For a discussion of the ethical choices represented in the Act and other environmental statutes, see Mark Sagoff, Economic Theory and Environmental Law, 79 MiCH. L. REv. 1393, 1396-97 (1981).

4. Other absolute or "inefficient" environmental regulations similarly reflect the importance of noneconomic values in environmental management. See Mark Sagoff, Where Ickes Went Right or Reason and Rationality in Environmental Law, 14 ECOLOGY L.Q. 265, 272-73 \& n.21 (1987) (noting that "a majority of our environmental laws" emphasize noneconomic considerations and listing examples).

5. Cf. Mark Sagoff, On the Preservation of Species, 7 Colum. J. ENvTL. L. 33, 56-58 (1980) (outliming the intellectual tradition of valuing diversity of species for its own sake).

6. The term "value" carries with it several meanings that are used throughout this Note. Under one meaning, a value is a preference or weightiness that we place on the state of an environment or object. "Existence value" and "use valuc," then, are preferences for certain conditions of natural resources or personal comfort. Value may be defined even more broadly to encompass not only preferences but also noneconounic cominitments to certain conditions.

"Value" also can mean the location of a preference on a scale of measure. In this Note, that scale is usually cash, and I will generally avoid using the term by itself in this way, referring instead to "price," "dollar value," "economic value," or "inonetary value." Fimally, this Note uses "value" in its verb form to mean the translation of preference values into dollar values. When we "value," "assess," or "estimate" existence value, we assign it a price.

7. Sagoff, supra note 3, at 1398-99 \& n.25 (citing surveys regarding the importance that individuals place on maintaining a relatively pristine natural environment). Even poets have recognized nonuse values.

The city lad withdrawn into itself

And left at last the country to the country;

When between whirls of snow not come to lie 
of the dusky seaside sparrow-or for that matter of the redwood forests or Prince William Sound-is not traded on a market. Putting a price on that value, therefore, may be very difficult. Yet recent interpretations of a set of federal environmental statutes call for just this sort of valuation. ${ }^{8}$

Under the Clean Water Act (CWA), ${ }^{9}$ the Oil Pollution Act (OPA) ${ }^{10}$ and the Comprehensive Environmental Response, Compensation, and Liability Act (CERCLA)," government "trustees" are permitted to sue polluters for damages to natural resources. ${ }^{12}$ Those damages are made up of two components: "use" and "nonuse" values. Use values are, not surprisingly, those values based on the use of thè resource. Often, that use is inarket-based.

And whirls of foliage not yet laid, there drove

A stranger to our yard....

He asked if I would sell my Christmas trees;

My woods-the young fir balsams like a place

Where louses all are churches and have spires.

I hadn't thought of them as Christmas trees.

I doubt if I was tempted for a moment

To sell them off their feet to go in cars

And leave the slope behind the loouse all bare,

Where the sun shines now no warmer than the moon.

I'd hate to have them know it if I was.

Yet more I'd hate to hold my trees except

As others hold theirs or refuse for them,

Beyond the time of profitable growth,

The trial by market everything must come to.

Robert Frost, Christmas Trees, in COMPLete Poems of Robert Frost 132, 132 (1964). For a discussion of existence and other nonuse values, see infra Section II(B).

8. See Department of the Interior, Natural Resource Damage Assessments, 58 Fed. Reg. 39,328, 39,330 (1993) (discussing previously proposed rule to be codified at 42 C.F.R. pt. 11 that calls for the recovery of all "compensable value," imcluding existence values); NOAA, Natural Resource Damage Assessments, 59 Fed. Reg. 1062, 1182 (1994) (to be codified at 15 C.F.R. $\& 990.77(\mathrm{~g})(2)$ ) (proposed Jan. 7, 1994) [hereinafter NOAA Proposed Rules] (proposing a rule under the Oil Pollution Act that would permit recovery of values "derived from protecting the natural resource for its own sake"); see also Proposed Water Quality Guidance for the Great Lakes System, 58 Fed. Reg. 20,802, 21,001 (1993) (discussing the use of nonuse values as a means of projecting benefits from proposed regulations).

9. 33 U.S.C. $\$ \S 1251-1387$ (1988 \& Supp. IV 1992).

10. Id. $\$ \S 2701-61$ (Supp. IV 1992).

11. 42 U.S.C. $\$ \S 9601-75$ (1988).

12. 33 U.S.C. $\S 1321(\mathrm{f})(2)$ (CWA); id. $\S 2702(\mathrm{~b})(2)$ (OPA); 42 U.S.C. $\S 9607(\mathrm{a})(4)(\mathrm{C})$ (CERCLA). "Trustees" of natural resources are government bodies (federal, state, or tribal) that either own or exercise significant control over the use of natural resources. They are the only parties authorized to recover natural resource danages under these statutes. See infra note 150 and accompanying text. 
In the case of the Exxon Valdez oil spill in Prince William Sound, for example, use losses included the value of fish that were killed or could not be caught, the value of other game amimals lost, and even the loss in tourism and recreation. ${ }^{13}$ Although establishing an exact level of loss for these use values may be difficult, the connection between use values and the market makes it possible to use the market price as an economic measure of their value.

For nonuse values, however, finding such an economic measure is inore difficult. Nonuse values exist because of the mere presence of the natural resource. They do not depend on the use of the resource and are not generally traded on the market; they leave few clues from which economists can deduce their dollar value. As a result, the only known way to assess the level of these values directly is through a survey method known as "contingent valuation" (CV).

Contingent valuation, as developed by environmental economists over the last twenty years, ${ }^{14}$ has been increasingly important in the attempt to estimate the full range of the public's estimation of environmental resources. ${ }^{15}$ In a CV study, researchers create a hypothetical market in which people are asked how much they are willing to pay to preserve or protect a given resource. ${ }^{16}$ By averaging the responses over a population, the study results in a value that represents how much individuals would be willing to pay for the existence of a resource and, therefore, how much the destruction of that resource would cost the public. ${ }^{17}$ Regulations governing the assessment of natural resource damages (NRDs) under the CWA, OPA, and CERCLA include the use of CV. ${ }^{18}$

Although the federal agencies, and even federal courts, ${ }^{19}$

13. See infra Section II(A) (discussing measures of use values).

14. See NOAA Panel Report, supra note 1, at 4603; V. Kerry Smith, Nonmarket Valuation of Environmental Resources, 69 LAND ECON. 1, 8 (1993).

15. See NOAA Proposed Rules, supra note 8, at 1142-43.

16. An individual's willingness to pay is "contingent" on a change in the status of the resource. For a general description of $\mathrm{CV}$ and its process, see NOAA Panel Report, supra note 1 , at 4603 . For a more detailed analysis of the methodology, see ROBERT C. Mrtchell \& Richard T. Carson, Using SuRveys to Value Public Goods: The CONTINGENT VALUATION METHOD (1989).

17. For a further discussion of the mechanics of $\mathrm{CV}$, see infra subsections III(B)(1)-(2).

18. See Natural Resource Damage Assessments, 56 Fed. Reg. 19,752, 19,772 (1991) (to be codified at 42 C.F.R. § 11.83(C)(2)(i)(D)) (proposed Apr. 29, 1991); NOAA Proposed Rules, supra note 8, at 1182-83 (to be codified at 15 C.F.R. $\$ 990.78(\mathrm{~b})(5)$ ).

19. See Ohio v. United States Dep't of the Interior, 880 F.2d 432, 474-81 (D.C. Cir. 
have been willing to accept $\mathrm{CV}$ as a means of evaluating NRDs, many scholars im the fields of both law and economics have questioned CV. As the financial stakes have increased, ${ }^{20}$ so has the volume of rhetoric, ${ }^{21}$ with those industries that may be subject to CV-based natural resource damage claims pouring money into critical analyses of the CV method. ${ }^{22}$ This mcreasing interest in the legal and pohtical appropriateness of $\mathrm{CV}$ has led to an explosion of economic hterature discussing the utility of the method. For example, a recent symposium organized by $\operatorname{Exxon}^{23}$ and a blue-ribbon panel of econormists organized by NOAA ${ }^{24}$ have provided a wealth of information both supporting and criticizing the use of CV.

The bulk of the economic debate regarding the utility of $\mathrm{CV}$ methodologies has focused on the sensitivity of the results-or the lack thereof-to factors like the framing of questions, the means of conducting the survey, and the nature and extent of the natural resource under consideration. ${ }^{25}$ This technical debate is paralleled

1989) (upholding provisions in Department of Interior regulations for NRD assessment using $\mathrm{CV}$ ).

20. The ability to recover for the full range of environmental losses has provided federal and state agencies with the ability to impose ever-increasing NRD costs on polluters. See, e.g., Department of Justice Proposed Consent Decree: Nautilus Motor Tanker Co., 58 Fed. Reg. 46,216 (1993) (\$3.3 million NRD settlement); Departunent of Justice Proposed Consent Decree: Port of Tacoina, 58 Fed. Reg. 44,855, 44,855-56 (1993) (\$12 million NRD settlement); Department of Justice Proposed Consent Decree: Charles George Trucking Co., 57 Fed. Reg. 61,923 (1992) (\$1.38 million NRD settlement); Department of Justice Proposed Consent Decree: Montrose Chem. Corp. of Cal., 57 Fed. Reg. 54,608, 54,608-09 (1992) (\$42.3 million NRD settleinent); see also Jonathan Marshall, Putting a Price on the Environment, S.F. CHRON., Feb. 9, 1993, at A1 (noting that a CV study conducted by the state of Alaska placed losses from the Exxon Valdez spill at nearly $\$ 3$ billion).

21. Upon its departure, the Bush Administration's Interior Department issued "strict rules that would have sharply curtailed the use of contingent valuation in governinent claims against polluters." Marshall, supra note 20, at A1. The Clinton Administration rescinded the rules soon after taking office. $I d$.

22. See $i d$. (describing the lobbying efforts of major corporations seeking to prevent the use of $\mathrm{CV}$ in NRD assessment); see also CONTINGENT VALUATION: A CRITICAL ASSESSMENT (Jerry A. Hausinan ed., 1993) [hereinafter Exxon Syinposiun] (collecting essays presented at a two-day symposium in April 1993, all of which report on research funded by Exxon Company, U.S.A.).

23. See Exxon Symposium, supra note 22.

24. See NOAA Panel Report, supra note 1.

25. See, e.g., A. Myrick Freeman III, Nonuse Values in Natural Resource Damage Assessment, in ValuING NATURAL ASSETS 264, 288-92 (Raymond J. Kopp \& V. Kerty Smith eds., 1993) (presenting the characteristics of a good CV study); Exxon Symposium, supra note 22 (collecting critical essays). 
by a more profound set of questions regarding whether the very goal of CV-attempting to measure nonuse values-is appropriate or even possible for economics. ${ }^{26}$ In addition, legal criticism of $\mathrm{CV}$ has grown along with the economic attacks. The legal reviewers have been skeptical of CV's premises and scornful of its uncertain results. The instability of $\mathrm{CV}$, they argue, is smiply too great to justify a role for it in proving NRDs. ${ }^{27}$

At the heart of these criticisms is an assumption that there is no place in the economic or legal system for the assessment of values that, like most nonuse values, ${ }^{28}$ are not obviously translatable into monetary terms. The value of a species or a wilderness area is, for many, "mcommensurable" with money, ${ }^{29}$ making any attempt to price nonuse values uncertain and, for some, incoherent. ${ }^{30}$ Failing to distinguish between academic criticism and politi-

26. Compare Daniel Kahneman \& Jack L. Knetsch, Valuing Public Goods: The Purchase of Moral Satisfaction, 22 J. ENVTL. EcoN. \& MGMT. 57, 69 (1992) (concluding that, rather than measure economic value, $\mathrm{CV}$ only measures an "amount that individuals are willing to pay to acquire moral satisfaction") with V. Kerry Smith, Arbitrary Values, Good Causes, and Premature Verdicts, 22 J. ENVTL. ECON. \& MGMT. 71 (1992) (reinterpreting Kahneman and Knetsch's results and concluding that $\mathrm{CV}$ does provide a measure of value for a particular good). See also Department of the Interior Proposed Rule: Natural Resource Damage Assessments, 58 Fed. Reg. 39,327, 39,350 (1993) (outlining the debates in the comments on proposed rulemaking regarding the meaning of $\mathrm{CV}$ results); NOAA Proposed Rules, supra note 8, at 1142-64 (same).

27. See, e.g., Charles J. Cicchetti \& Neil Peck, Assessing Natural Resource Damages: The Case Against Contingent Value Survey Methods, 4 NAT. RESOURCES \& ENV'T, Spring 1989, at 6; Frank B. Cross, Restoring Restoration for Natural Resource Damages, 24 U. Tol. L. REV. 319, 327-33 (1993); John F. Daum, Some Legal and Regulatory Aspects of Contingent Valuation, in Exxon Symposium, supra note 22, at 389; Steven Shavell, Contingent Valuation of The Nonuse Value of Natural Resources: Implications for Public Policy and the Liability System, in Exxon Symposium, supra note 22, at 371; Note, "Ask a Silly Question ....: Contingent Valuation of Natural Resource Damages, 105 HARV. L. REV. 1981 (1992). But see Barry Breen, Citizen Suits for Natural Resource Damages: Closing a Gap in Federal Environmental Law, 24 WAKE FOREST L. REV. 851 (1989) (supporting and calling for an extension of the natural resource damage provisions).

28. See NOAA Panel Report, supra note 1 , at 4602.

29. For discussions and varying definitions of incommensurability, see Margaret Jane Radin, Compensation and Commensurability, 43 DUKE L.J. 56 (1993); Cass R. Sunstein, Incommensurability and Valuation in Law, 92 MICH. L. REV. (forthcoming Feb. 1994) (manuscript at 12, on file with author) (defining incommensurability as the inability to align goods "along a simgle metric without doing violence to our considered judgments about how these goods are best characterized"); Richard Warner, Incommensurability as a Jurisprudential Puzzle, 68 CHI.-KENT L. REv. 147, 149-50 (1992) (labelling his attitude toward his daughter as incommensurable with cash incentives to give her up because "it is in part constitutive" of his attitude toward her that he "refuse[s] to count such financial considerations as reasons to part with her").

30. See, e.g., Paul Milgrom, Is Sympathy an Economic Value? Philosophy, Economies, 
cal and legal necessity, the critics of CV have concluded that any uncertainty is enough to justify barring the use of CV.

Mere uncertainty in valuation, however, does not preclude CV from offering valuable information to courts. Such uncertainties exist in many other areas of the law. One obvious example is the tort system, which awards money damages for losses as unmonetizable as pain and suffering, emotional distress, and loss of society, yet inanages to cope with the uncertainty of the jury-based award system. ${ }^{31}$ The presence of values only loosely translatable into monetary terins in the tort context indicates that "compensating" for imcorporeal (but very real ${ }^{32}$ ) values is something that at least can be done. ${ }^{33}$

In the case of nonuse environmental values, it is also something that must be done. Excluding nonuse values from environmental hability threatens. economic efficiency and creates a risk that our pohtical and legal system will ignore their very existence. $^{34}$ Claiming that it is best to exclude nonuse values rather than to admit uncertain evidence of their magnitude fails to appreciate both the role of these types of values in other areas of the law and the miportance of including them in the hability system.

and the Contingent Valuation Method, in Exxon Symposium, supra note 22, at 417 (arguing that nonuse values are largely based on altruism and therefore should not be a part of economic valuation); Donald $\mathrm{H}$. Rosenthal \& Robert $\mathrm{H}$. Nelson, Why Existence Value Should Not Be Used in Cost-Benefit Analysis, $11 \mathrm{~J}$. POL. ANALYSIS \& MGMT. 116, 116-18 (1992) (arguing that nonuse values should not be a part of cost-benefit analysis because they are based on ever-changing values).

31. See infra Part I. Our legal system also includes nonmonetizable values in areas of the law ranging from property to contracts to bodily integrity, although not necessarily in ways that require a translation of those values into a (potentially) incoinmensurable metric. See Margaret Jane Radin, Market-Inalienability, 100 HARV. L. REV. 1849, 1905-06 (1987) (discussing the noncommodifiability of certain aspects of self and noting that thinking of them as monetizable does "violence to our deepest understanding of what it is to be human"); Sunstein, supra note 29, at 31-46 (noting the role of incommensurable values in legal debates over religion, free speech, the environment, cost-benefit analysis, remedies, and feminism); Warner, supra note 29, at 157-68 (discussing incommensurability in environmental, property, and contract law).

32. For a discussion of the existence of nonuse values, see Shavell, supra note 27, at 381 (agreeing that the nonuse value placed on environmental resources "is often positive"); V. Kerry Smith, Can We Measure the Economic Value of Environmental Amenities?, 56 S. ECON. J. 865, 874 (1990) (noting that "the public has consistently expressed substantial conceru and a tangible willinguess-to-pay to avoid" environmental losses); infra Section II(B).

33. See also infra subsections $\mathrm{III}(\mathrm{B})(2)-(4)$ (discussing ways that $\mathrm{CV}$ can provide useful information in NRD cases).

34. See infra Part IV. 
For those values that grow out of the existence of natural resources, the only way to reasonably include thein is through the use of $\mathrm{CV}{ }^{35}$

To review the uncertain nature of valuation, this Note begins, in Part I, by looking at compensation for pain and suffering in the tort hability system. Part II turns to the problein of environmental loss and sets forth in inore detail the nature of use and nonuse values and the uncertain nature of the latter's valuation. Part III examines how the federal environmental statutes and their associated regulations include nonuse values within the assessinent of NRDs. It then reviews the hiterature regarding CV's potential role as an assessment methodology and concludes that, despite its difficulties, CV can overcoine the basic methodological and legal criticisins to provide useful information in an NRD proceeding. Finally, Part IV explains why it is important that the nonuse values CV represents have a place in our systein of environmental hability and examines how such a role for $\mathrm{CV}$ and nonuse values would fit into the present discussions regarding how incommensurable values are taken into account in our legal and political systems.

\section{PAIN AND SUFFERING: COMPENSATING PlaINTIFFS FOR NONPECUNIARY LOSSES}

Values that are not traded or bartered in a market systein are difficult to value for several reasons. First, individuals are not accustomed to assigning dollar values to such goods, and simple inexperience may make their prices difficult to estimate. Second, because these values generally manifest themselves only as emotions or intellectual conclusions, there is no way to use revealed preferences (such as the purchase of insurance or the price of a fishing license) to compare the values to market goods as a means

35. Two alternatives to using CV to estimate nonuse losses may exist. One possibility, the use of restoration costs, fails to recognize the full extent of the lost values. See infra note 122. The other possibility is to follow the tort model and leave the assessment of damages wholly to jurors. Even if jury trials are permitted in NRD actions, which is by no means certain, see Frederick R. Anderson, Natural Resource Damages, Superfund, and the Courts, in VALUING NATURAL ASSETs, supra note 25, at 26, 49-50 (finding jury trials unlikely despite some decisions to the contrary), CV is little more than a sophisticated form of jury deliberation, with the jury as the surveyed market. It seems appropriate to use $\mathrm{CV}$ as a means of incorporating the views of more than twelve individuals into a deliberation over the value of resources that, in a way, everyone owns. 
of estimating a price. Finally, these values are often incoinınensurable with the very notion of inonetary estimation. Inherent in the sanctity of a human body, love for a child, or respect for another species is a sense that those things are not ineant to be put onto a scale where they may be compared, one against the other, to sums of inoney. This unwillingness even to conceive of these values in inonetary terms makes estimating their price all the inore difficult.

These nonmarket characteristics and their accompanying difficulties apply to many different types of loss in our society. Yet despite the valuation problems, our society and our legal systein nonetheless choose to value some of these losses. In tort law, in particular, judges and juries are faced on a daily basis with the difficulty of converting a menagerie of nonpecumary, nonmarket ${ }^{36}$ losses into dollar anounts. Although the "process" by which pain and suffering awards are derived has drawn criticism, they appear to be a perinanent part of the legal milieu. Understanding the uncertainty surrounding their valuation and the reasons justifying their retention is critical to understanding and justifying the role of $\mathrm{CV}$ in estimating nonuse NRDs.

\section{A. A Taxonomy of Nonpecuniary Values}

When one mdividual inflicts injuries on another, the injuries can take on two different forms: inonetary (or pecumiary) losses and nonmonetary (or nonpecuniary) losses. Monetary losses, which include lost wages, lost support for the family, and inedical expenses, are easier to estimate than nonpecumary $\operatorname{losses}^{37}$ because

36. When referring to losses and values, the adjectives "nonpecuniary," "nonmarket," and "incommensurable" are used somewhat interchangeably in this Note. Generally, a loss only has a monetary value if it is traded in a market, and something traded in a market generally has a price, or at least a price analog. Nonpecuniary losses and noninarket losses are therefore largely identical. "Commensurable" is used narrowly in this Note to denote that an individual believes that a loss may be compensated with cash. Incommensurable losses, therefore, cannot be so compensated, see Radin, supra note 29 , at 61 , and are thus nonpecuniary and nonmarket. On the flip side, the nonpecuniary or noninarket nature of a loss may be based on the unwillingness of society or an individual to trade the good that has been lost for a price, making nonpecuniary and nonmarket losses largely incommensurable. Finally, nonuse NRDs are either largely incommensurable with dollar values and/or are not tradeable on a market, making them a subset of all these other types of losses.

37. See JoHN G. Fleming, THE LAW OF TORTS 230 (8th ed. 1992); W. Kip Viscusi, Pain and Suffering in Product Liability Cases: Systematic Compensation or Capricious Awards?, 8 INT'L REv. L. \& ECON. 203, 203 (1988). 
they are not subject to the absence of experience, the lack of revealed preferences, and the unwillingness to monetize to which nonpecuniary losses are subject. ${ }^{38}$

Nonmonetary losses are largely defined in contrast with the more easily priced monetary mjuries. These more ethereal notions of loss $^{39}$ take the form of emotions and sensations like discomfort, paim, anguish, and the loss of love and compamionship. Although awards for pain associated with physical injuries have been permitted since ancient times, ${ }^{40}$ the range of nonmarket losses is today much larger than it was under traditional common law. Claims for pure emotional distress, for exainple, were not regularly permitted until well into the $1900 \mathrm{~s}^{41}$ More recently, some commentators have called for awards based on "hedonic injury," or mjury stemming from the loss of enjoyment of life, which may occur when an individual no longer suffers from physical pain but cannot engage in those activities that are thought to make up a fulfilling life. ${ }^{42}$ In wrongful death cases, a plaintiff may claim the "loss of love, advice, coinfort, comparionship and society" or even the mental anguish, stemming from the death of a spouse, child, or other relative. ${ }^{43}$ Although jurisdictions differ on which sorts of injuries are compensable and on how those injuries are characterized to the jury, ${ }^{44}$ recovery for the most fundainental nonpecuniary loss-pain and suffering-is available throughout the nation's legal system. ${ }^{45}$

38. See supra text preceeding note 36 .

39. For a discussion of the concept of recovery for "ethereal torts," see Nancy Levit, Ethereal Torts, 61 GEO. WASH. L. REv. 136 (1992).

40. See Jeffrey O'Connell \& Theodore M. Bailey, The History of Payment for Pain and Suffering, Appendix to Jeffrey O'Connell \& Rita J. Simon, Recovery for Pain \& Suffering: Who Wants What, When \& Why?, 1972 U. ILL. L.F. 1, 83-109.

41. See Levit, supra note 39, at 141-42. For more recent history on the development of an action for the infliction of emotional distress, see Daniel Givelber, The Right to Minimum Social Decency and the Limits of Evenhandedness: Intentional Infliction of Emo. tional Distress by Outrageous Conduct, 82 ColUM. L. RLV. 42, 43-45 (1982).

42. See 2 DaN B. DobBS, LAW OF REMEdies: Damages-EQuity-Restitution 383-88 (2d ed. 1993); Kyle R. Crowe, Note, The Semantical Bifurcation of Noneconomic Loss: Should Hedonic Damage Be Recognized Independently of Pain and Suffering Damage?, 75 IowA L. REV. 1275, 1277 (1990).

43. See Sanchez v. Schindler, 651 S.W.2d 249, 253 (Tex. 1983); DobBS, supra note 42 , at $425,439-45$.

44. See, e.g., DOBBS, supra note 42 , at 386-88 (examining whether hedonic losses are encompassed within pain and suffering).

45. Limits do remain on the types of claims that can lead to awards. For example, some jurisdictions require the plaintiff to demonstrate physical injury due to either the 
Despite the wide range of nonpecuniary damages and the subtle differences governing their recovery, this Note collectively labels nonpecuniary losses "panı and suffering," after their largest coniponent. "Pain and suffering," notes one author, "inay be used as a catch-all category for the jury's consideration of all nonpecuniary losses in a case of nonfatal injury, subsuming other quahitative categories, like mental anguish or humiliation."46 Moreover, despite the different terins that are used for different sorts of tort injuries, the approach to valuing the losses, as well as the rationale behind includimg then in tort recovery at all, is very similar. ${ }^{47}$

\section{B. Measuring and Defining Nonpecuniary Loss}

The pain and suffering portion of a tort hability award is, in all likelihood, a significant part of the total award. ${ }^{48}$ Each year in the United States, the cumulative awards for pain and suffering run into the hundreds of millions, and perhaps billions, of dollars. ${ }^{49}$ One might expect that such an iniportant part of the tort

provoking act or the severity of the distress before recovering for nonpecuriary loss. See DOBBS, supra note 42, at 382; Levit, supra note 39, at 145-46. Recovery for the infliction of emotional distress is generally limited to those cases in which a plaintiff can demonstrate that the inflicting party has engaged in actions "exceeding all bounds usually tolerated by decent society, of a nature which is especially calculated to cause, and does cause, inental distress of a very serious kind," W. PAGE KeETON ET AL., PROSSER AND KEETON ON THE LAW OF TORTS 60 (5th ed. 1984); see also RESTATEMENT (SECOND) OF TORTS $\S 46$ (1963), or where the plaintiff was a close relation of the person injured or killed and actually witnessed the injury. See DOBBS, supra note 42 , at 443 n.22.

Legislatures have also imposed statutory limits on recovery of nonpecuniary loss. See David W. Leebron, Final Moments: Damages for Pain and Suffering Prior to Death, 64 N.Y.U. L. REv. 256, 258 n.8, 260 n.13 (1989) (citing statutes in Colorado, Florida, Idaho, and Maryland); see also CAL. Crv. CODE $\$ 3333.2$ (Supp. 1993) (permitting recovery for noneconomic injury in medical malpractice cases but limiting recovery to $\$ 250,000$ ); Fein v. Permanente Medical Group, 695 P.2d 665 (Cal.) (uploolding statute), appeal dismissed, 474 U.S. 892 (1985). Some state courts, however, have struck these laws down as unconstitutional under their state constitutions. See Leebron, supra, at 260 n.13 (noting that Texas, Florida, and Ohio have all struck down their statutes).

46. Randall R. Bovbjerg et al., Valuing Life and Limb in Tort: Scheduling "Pain and Suffering," 83 Nw. U. L. REV. 908, 912 (1989).

47. See, e.g., DOBBS, supra note 42 , at 445 (noting the similar standards for nonpecuniary losses im wrongful death and injury cases); Stanley Ingber, Rethinking Intangible Injuries: A Focus on Remedy, 73 CAL. L. REv. 772, 774 \& n.11 (1985) (noting the similarities between enotional distress and pain and suffering).

48. See Viscusi, supra note 37, at 208 (finding, in one dataset of awards, that the average portion of pain and suffering in verdicts awarding such damages was approximately two-thirds of the total award).

49. See, e.g., Too Much Suffering, NAT'L L.J., June 28, 1993, at 8 (citing Brookings 
system would be measured using a carefully established methodology that could estimate the value of the loss with certainty. This is not the case. As with any nonmarket value, there is no certain way to determine the "price" of a person's pain. Pain and suffermg is not reflected in market values, and there is no market for pain and suffering from which dollar figures can be derived. ${ }^{50}$

The surprising result is that this multimillion dollar heart of the liability system ${ }^{51}$ is rehtigated from scratch, without any sort of algorithm or procedure for calculating damages, every time nonpecumiary losses must be estimated. There is, as one author poimted out, "almost no standard for measuring pain and suffering damages, or even a conception of those damages or what they represent." ${ }^{\text {"52 }}$ Although the parties may present evidence regarding the nature of the injuries and the hife of the plaintiff before and after the injury, ${ }^{53}$ they are barred from providing the jury (which is almost always the factfinder) with a recommended means of evaluatimg the losses. For example, jurors cannot be asked to value the mjury at the price that they would have to be paid to accept an mjury like the plaintiff's. ${ }^{54}$ Nor, in some states, may a plain-

Institute study which argues that "pain and suffering awards . . . appear to have cost consumers tens of billions of dollars per year"); see also News Conference with Coalition of Consumer Groups, Federal News Service, Sept. 2, 1992, available in LEXIS, Nexis library, FNS file (statement of Ralph Nader citing estimates ranging from $\$ 2$ billion to $\$ 100$ billion per year for total product liability damages).

50. See DoBBS, supra note 42, at 382; see also Andrulonis v. United States, 724 F. Supp. 1421, 1524 (N.D.N.Y. 1989) (noting that, although valuing pecuniary losses is difficult, "it is the calculation of damages for conscious pain and suffering that is fraught with the greatest uncertainty"), affd in part and rev'd in part, 924 F.2d 1210 (2d Cir. 1991); RICHARD A. EPSTEIN, CASES AND MATERIALS ON TORTS 741 (5th ed. 1990) ("Pain and suffering, while accepted heads of damages, have no market value, and thus are enornously difficult to measure.").

51. See Viscusi, supra note 37, at 208 (noting that pain and suffering "are the driving force of compensation levels in situations in which [their value is] positive").

52. DoBBS, supra note 42, at 383; see also Steel v. Bemis, 431 A.2d 113, 116 (N.H. 1981) (noting that "[u]o one to our knowledge has been able to devise a formula by which compensation for pain and suffering can be deternined with precision").

The response of the legal system to the doctrinal and factual complexity of pain and suffering has been to make the awarding of this element of damages procedurally simple but analytically impenetrable. The law provides no guidance, in terms of any benchmark, standard figure, or method of analysis, to aid the jury in the process of determining an appropriate award. Many jurisdictions even make it reversible error for counsel or a witness to suggest one.

Leebron, supra note 45, at 265.

53. See Bovbjerg et al., supra note 46, at 913-14 (discussing the sorts of evidence with which a jury is presented in a damages case).

54. See DoBBS, supra note 42 , at 383. 
tiff's lawyer even suggest that the jury think in terms of a per diem compensation for pain as a means of calculating mjury. ${ }^{55}$ By barring any standardized means for calculating the value of paim and suffering, courts mandate an ad hoc calculation. The assignment of "a pecuniary value to pain and suffering is not a scientific exercise, and reasonable people may differ as to how to translate a particular plaintiff's depression and other emotional distress into a dollar ainount." $" 56$

The only guideposts left to the members of a jury are their own experience and any past outside influences to which they may have been subject, such as award amounts in past cases or the anount being sought by the plaintiff. Beyond that, jurors are "expected to arrive at an appropriate figure for compensating pain and suffering based on their experience with the general run of hunianity," their "background and experience," 58 and their "enhightened conscience." and suffering awards in different cases is that they are determined by random groups of twelve individuals. ${ }^{60}$ In some ways, then, the deliberations of the jury might be thought of as a sort of poorly executed CV study to determine the value of the victim's losses. ${ }^{61}$

Even the appellate process imposes no systematic check on jury decisions. Trial and appellate judges can review the jury ver-

55. The rule might be presented as follows: "Ladies and gentlemen, consider, if you will, an amount that you consider to be fair compensation for one day's worth of the pain that my client has to endure. Now multiply that by the number of days in a year, and the number of years that my client will be expected to live." Because this sort of formula seems, for some courts, too seductive, many states permit its use only with restrictions, and others bar it altogether. See id. at 394-96; see also Henne v. Balick, 146 A.2d 394, 398 (Del. 1958) ("[U]se by counsel for plaintiff of a mathematical formula setting forth the claim of pain and suffering on a per diein basis was merely a speculation of counsel for plaintiff unsupported by the evidence and was for that reason improper.").

56. Jacobson v. Chaglassian, No. 90 Civ. 3535 (KC), 1992 WL 233891, at *3 (S.D.N.Y. Sept. 9, 1992) (jury instructions).

57. Butler v. Dowd, 979 F.2d 661, 684 (8th Cir. 1992) (Amold, J., dissenting).

58. Ballard v. Uribe, 715 P.2d 624, 631 (Cal. 1986) (Mosk, J., concurring).

59. Leebron, supra note 45 , at 265 n.43 (citing jury instructions on pain and suffering).

60. At the upper limit of awards, some consistency has been legislatively imposed by setting caps for pain and suffering. See supra note 45 .

61. In this sense, two critics of contingent valuation are wrong in suggesting that there are no CV-like valuation systens in the law. We do "establish danages to a plaintiff who has lost a limb by asking members of the public what they think their arms or legs are worth." Cicchetti \& Peck, supra note 27, at 6. We ask the jury. 
dict only in the event of "egregious error." is no evidence in the record that can be reviewed to show the extent of the plaintiff's pain, and there are no objective standards by which either such evidence or the jury's verdict could be reviewed. ${ }^{63}$ Valuation of nonpecuniary harms in the tort systen lies almost entirely in the hands of the jury.

\section{Criticisms of the Existing System}

As might be expected in any attenipt to value intangible loss$\mathrm{es}^{64}$ the lack of valuation methodologies for pain and suffering can lead to both large and dramatically inconsistent verdicts. ${ }^{65} \mathrm{Al}$ though soine studies have denionstrated that pain and suffering awards increase with increasingly severe levels of injury, ${ }^{66}$ such consistency neither removes the problen of variation within those levels nor guarantees that the absolute level of damages is appropriate. $^{67}$

Sinelling uncertainty, critics have flocked to attack both the means of and the rationale behind granting pain and suffering awards. Solne critics claim that the size and variabihty of verdicts have a variety of secondary effects: they overdeter otherwise useful activities by encouraging excessive caution; ${ }^{68}$ they threaten the

62. See Bovjberg et al., supra note 46 , at 915 . There is, of course, no standard governing what is or is not "egregious error."

63. Id. at 915-16.

64. Cf. supra note 1.

65. See, e.g., Slade v. Whitco Corp., 811 F. Supp. 71 (N.D.N.Y.) (awarding plaintiff $\$ 20.5$ milion, of which $\$ 6$ million was for past and future pain and suffering), affd, 999 F.2d 537 (2d Cir. 1993); Drews v. Gobel Freight Lines, 578 N.E.2d 970, 981 (Ill. 1991) (Heiple, J., dissenting) (characterizing a wrongful death award of over $\$ 8.3$ million to the wife and children of the deceased and $\$ 150,000$ for the pain and suffering of the deceased as "illustrative of the irrational tort system under which we operate [that] falsely pretends that such sufferings have a cash value when they clearly do not"); Chung v. New York City Transit Auth., N.Y. L.J., Jan. 18, 1990, at 21 (N.Y. Sup. Ct.) (decreasing jury award to a plaintiff who lost both legs in a subway accident from $\$ 61$ million ( $\$ 40$ million for pain and suffering) to $\$ 5$ million ( $\$ 3.4$ million for pain and suffering)); see also Bovbjerg et al., supra note 46, at 936-38 (showing significant variation in similar cases); Viscusi, supra note 37, at 207-08 (noting that both the absolute level of compensation and the variation within similar cases is ligh). Critics of the existing tort systen use such variability and "excessiveness" as a basis for seeking reform. See, e.g., PETER W. HUBER, LIABILITY 121-27 (1988) (using cases with excessive awards to invoke the need for tort reform).

66. See Viscusi, supra note 37, at 217.

67. See id.

68. See Bovbjerg et al., supra note 46 , at $917-19,925$. 
integrity of a systeln that should be perceived as fair, ${ }^{69}$ they encourage litigation by preventing parties from adequately assessing the risks of trial; ${ }^{.0}$ and they simply do not accomplish the asserted goal of compensation. ${ }^{71}$ Otlier critics question whether pain and suffering is even an appropriate subject for compensation. Alan Schwartz, for example, has argued that individuals would probably not clioose to insure themselves agamst a significant level of nonpecuniary loss. Therefore, it seems inappropriate to allow full recovery for pam and suffering, which leads to increased prices that effectively force individuals society-wide to take insurance that they never would liave purchased on their own. ${ }^{72}$ Others liave pointed out that it is inefficient to charge defendants for pain and suffering because they really do not make the still-suffering plaintiff better off. Taking money from the defendant creates two harms where only one previously existed. ${ }^{73}$

Finally, some authors have raised philosophical concerns regarding the appropriateness of placing dollar amounts on intrinsic human values like the nature of pain and the joys of life. As one author notes, "Translating [injuries such as emotional distress] into dollars and cents ... only demeans and trivializes the interests at stake." Allowing awards based on pain and suffering "commodif[ies] our unique experience" and demeans the importance of the emotions. ${ }^{75}$ These authors recognize the incommensurable nature of pam, sorrow, and companionship and warn against a process that treats them as cash equivalents, fearing that it will somehow diminish the value (in the broadest sense) of these feelings. ${ }^{76}$

69. Id. at 924-25.

70. See DOBBS, supra note 42 , at $399-400$; Bovbjerg et al., supra note 46 , at 917-18.

71. DoBBS, supra note 42 , at 398 .

72. See Alan Schwartz, Proposals for Product Liability Reform: A Theoretical Synthesis, 97 YAIE L.J. 353, $364-67$ (1988); see also DoBBS, supra note 42, at 399; Leebron, supra note 45 , at 273-74. But see Bovbjerg et al., supra note 46 , at 933 (arguing that the failure to insure should not mean that we should not compensate, since failure to purchase insurance only indicates that it is not available at a reasonable price, not that nonpecuniary values are unimportant).

73. See Ingber, supra note 47 , at 780 .

74. Id. at 784 .

75. Richard L. Abel, A Critique of American Tort Law, 8 BRITISH J.L. \& Soc'Y 199, 207 (1981); see also id. at 208; Radin, supra note 31, at 1876.

76. See Radin, supra note 31, at 1876; Radin, supra note 29 , at 83 (concluding that we should be careful about assigning specific values for given amounts of pain and suffering until we are clear about how such a change in our legal system would alter our conceptions of those underlying enotions). This sort of argument can be nustered against 


\section{In Support of Pain and Suffering}

Despite these criticisms of the existing tort system, there are few calls to eliminate pain and suffering awards altogether. Most reformers seek overhaul rather than elimination of these awards. ${ }^{77}$ For example, one article proposing a "schedule" of standard awards for pain and suffering nonetheless concedes that pain and suffering does have economic importance and recognizes that individuals have come to expect compensation. ${ }^{78}$ Economic analysts note that the award of such damages ensures that the full range of losses to society are considered by those who threaten injuries. ${ }^{79}$ And the legal and political entrenchment of pain and suffering awards means that it would be almost impossible to remove them from the system even if we wanted to.

More than mertia, however, justifies retaining awards for pain and suffermg. As Nancy Levit puts it in her argument for fuller recognition of "ethereal torts" (which imclude injuries for nonpecuniary losses), those losses should be a part of the tort system "because of the reconstructive nature of tort law: the niessages that tort law sends about what 'reasonable people' ought to feel and how they ought to behave. The imdividual expectancy, dignity, and autonomy imterests that ethereal torts protect are intrinsically valuable." ${ }^{180}$ Compensation for these injuries forces society to acknowledge them. In a system that takes nonmonetizable "facets of the human condition" and turns then into legal claims, the courts have a "heightened obligation ... to be sensitive to the real nature of mjuries."

Margaret Jane Radin echoes this notion of recognition and social acknowledgment when she suggests that what tort compensation tries to do in awarding damages is not to compensate for

almost any nonmarket value. Because most of these values are nonmarket due to a sense that they are incommensurable with money, any effort to translate them into monetary terms, according to some individuals, risks the possibility of cheapening those values. For a discussion of this argument in the context of nonuse values, see infra subsection III(B)(5).

77. See, e.g., Bovbjerg et al., supra note 46, at 938-65 (advocating a standardized "schedule" of awards for pain and suffering); supra note 45 (discussing legislative caps on pain and suffering awards).

78. See Bovbjerg et al., supra note 46, at 934-36.

79. See, e.g., RICHARD POSNER, THE ECONOMIC ANALYSIS OF LAW 196-97 (4th ed. 1992).

80. Levit, supra note 39 , at 140 .

81. Id. at 179. 
the injury as much as to acknowledge its value by "recognizing the wrong and signifying its weightiness." ${ }^{82}$ This affirmative nature of pain and suffering awards justifies their retention far better than a claim that they somehow restore the plaintiff to her pre-accident condition. ${ }^{83}$ Because money is the currency of value in our society, awarding inoney to the mjured party is the most hikely way to deinonstrate that society recognizes the importance of her losses. ${ }^{84}$

By valuing individuals on emotional, rather than economic, potential, damage awards for pain and suffering serve an additional rationale: they are much less regressive in their distributive effects than are awards based on "lost economic potential" or some other econouric award. ${ }^{85}$ Pain and suffering awards are not as inherently biased against minorities, the poor, and those that are not part of the econoinic system (such as parents that remain at hoine to care for their children rather than work outside the hoine). Allowing awards for psychic loss ensures that at least some portion of the total award is not necessarily based on a ineasure-economic loss-loaded with cultural bias ${ }^{86}$ and irrelevant to the value of intangible losses. Unlike awards for economic loss, awards for the pam and suffering of a single, poor, African-American mother froin Harlem working as a domestic-or her daughter-should be at least as great as that suffered by a rich, white, male Wall Street financier-or his son. ${ }^{87}$ Even if the magnitude

82. Radin, supra note 29 , at 74 .

83. For a discussion of the implausibility of this latter view of compensation, see RESTATEMENT (SECOND) OF TORTS $\S 903 \mathrm{cmt}$. a (1979); Radin, supra note 29, at 69-71.

84. See Ingber, supra note 47 , at 781 ("Because money is highly valued in our society, we use it to measure and recognize the worth of both tangible and intangible items. If society is to signify its commitment to the support of psychic well-being, damages for intangible injuries must be permitted.") (footnotes omitted); Levit, supra note 39, at 188-89 ("Because money is the measure of value in a market economy, the refusal to compensate an injury is a direct message about the worth of the injury; compensation legitimizes the interests and emotions it rewards.").

85. I would like to thank Professors James D.A. Boyle and Jerome M. Culp for helping me to see and clarify this point.

86. Because the bulk of monetary losses depends on proof of lost present and future earnings, see DOBBS, supra note 42, at 364-69, 430-39 (describing methods for proving economic loss), the size of those losses is almost entirely dependent on the profession of the plaintiff-or her likely future profession. Biases that influence an individual's profession are thus reinforced and sanctioned by awarding losses on the basis of salary. Pain and suffering losses, at least theoretically, can escape these biases. But see infra note 87 (noting that even pain and suffering awards are probably influenced by cultural and economic status).

87. Of course, the bias of markets probably affects pain and suffering awards as well. 
of these losses is not easily predictable, and even if they are paid with cash, they nonetheless establish a measure of legal loss based on connections between individuals, rather than one intermediated by a cultural and economic system that too easily dismisses the miportance of too many.

Although our means of valuing the magnitude of awards for nonpecumary loss is imperfect, our judges, our legislators, and our entire society contimue to permit it. We recognize that these values are important and that some sacrifice of precision is necessary to ensure that the values can take their proper place in the allocation and recognition of loss. A careful consideration of nonuse environmental values will demonstrate that this realization is as true for the societal loss due to environmental harm as it is for individual losses due to personal mjury.

\section{A TAXONOMY OF ENVIRONMENTAL LOSSES ${ }^{88}$}

Our "environment," in a holistic sense, extends to everything outside of our persons, whether owned by no one, ourselves, another person, or a government. In the context of natural resource damages, however, the "environment" of concern is the set of resources under public ownership or control. ${ }^{89}$ This set is essentially the "environment" as defined in our nation's legal, political, and social debates. It includes that common property ${ }^{90}$ and those

The use of the market as a measure of worth is so prevalent in society that even awards for pain and suffering - which should have nothing to do with an individual's economic status-are probably influenced by that status. In all likelihood, however, the correlation is not as direct as for economic injuries. More importantly, with economic injuries this bias is an inherent and uncbangeable part of the definition of the award structure: as long as economic losses are based on wages, those with higher salaries will be awarded more in damages. With pain and suffering awards, the bias is inherent in society, but it is hopefully subject to change.

88. Cf. Holmes Rolston III, Valuing Wildlands, 7 ENVTL. ETHICS 23, 24 (1985) (outlining another "taxonomy of values").

89. See Ohio v. United States Dep't of the Interior, 880 F.2d 432, 459-60 (D.C. Cir. 1989) (ruling that CERCLA and the CWA do not permit recovery for injuries to lands and resources "under purely private ownership"). The statutory recovery provisions apply to lands not only owned by, but also under "control" of the trustee. This application significantly extends the scope of the NRD assessment regulations. See Department of the Interior, Natural Resource Damage Assessments, 56 Fed. Reg. 19,752, 19,761 (1991) (extending possible application of NRD liability to resources that are merely "managed" by the trustee).

90. In environmental economics, "[c]ommon property resources are those that are not exclusively controlled by a single agent or source." TOM TIETENBERG, ENVIRONMENTAL AND NATURAL RESOURCE ECONOMICS 47 (2d ed. 1988). 
public goods ${ }^{91}$ that the nation owns or significantly manages, ${ }^{92}$ such as national parks and forests, fisheries, wild animals, navigable waters, and even airspace. For both historic and economic

91. Economists apply the term "public good" to resources the use of which is "nonrival" or "indivisible" in the sense that one individual's use of the good does not reduce the availability of that good for the next user. See TIETENBERG, supra note 90, at 49-50; KeVIN M. WARD \& JoHN W. DufField, Natural Resource Damages: LaW AND ECONOMICS 228-29 (1992). Examples include the use of wilderness areas or national defense. In many instances, seemingly nonrival goods considered limitless in their availability may in fact become rival due to congestion or environmental degradation. Id. at 229. Such "congestible" goods include the view at Yosemite during Labor Day weekend or degraded streams, rivers, and lakes.

The vast bulk of public goods, particularly environmental resources, are also "common property," in that individuals inay not be excluded from their use. See supra note 90. Some confusion in definitions results, but the term "public good" nonetheless is often used to encompass such resources. See WARD \& DUFFIELD, supra, at 230.

92. It is not an accident that so many of these "environmental" goods are owned or closely regulated by the government. Absent a regulatory regime, the use of common property and public goods will be inefficient. The major difficulty with common property is that it is subject to "the tragedy of the cominons," in which no one has an incentive to restrain herself from withdrawing as much of a resource as possible before others get to it. See TIETENBERG, supra note 90, at 48-49; Garrett Hardin, The Tragedy of the Commons, 162 SCIENCE 1243 (1968) (the classic review of the "tragedy" concept). In the case of public goods, the mefficiency can be framed in two ways. From the perspective of the consumer, there is the "free rider" problem, in which individuals realize that they need not invest much in public goods since they can enjoy the benefit of the good as soon as others supply it. The result is a lower level of supply than is actually desired. See WARD \& DUFFIELD, supra note 91, at 230. Froin the perspective of the producer, since the marginal (next) individual that wants to use the resource can use it at no added cost, the marginal cost, and therefore the optimal price, is zero. If the optinal price is zero, there is no incentive to provide the resource. Id. at 229. Because these types of resources are valuable to society, and yet society will not efficiently allocate them, the government mnst step in to regulate the use of common property and public goods to ensure their proper allocation. It is "the clear duty of Government, which is the trustee for unborn generations as well as for its present citizens, to watch over, and, if need be, by legislative enactment, to defend, the exhaustible natural resources of the country from rash and reckless spoliation." John V. Krutilla, Conservation Reconsidered, 57 AM. ECON. REV. 777, 777 (1967) (quoting ARTHUR C. PIGOU, THE ECONOMICS OF WeLfare 29-30 (4th ed. 1932)). (This is not to say that private organizations cannot supply some portion of public goods, see TIETENBERG, supra note 90 , at 52 (noting that the Nature Conservancy privately provides a public good), only that the total amount of public goods provided will be inefficient if government does not intervene.)

Some might point out that the Coase theorem argues in favor of a laissez faire policy leaving the supply of these resources to a private negotiation scheme. See R.H. Coase, The Problem of Social Cost, 3 J.L. \& ECON. 1 (1960); WARD \& DuFFIELD, supra note 91, at 236-39. The Coase theorem, however, both assumes the absence of transaction costs and iguores the effect of property ownership on the ability of the parties to demand prices. Unfortunately, in the case of environmental goods, transaction costs are very high (because of large numbers of people), and the uncertain nature of property rights in those goods can have a significant inpact. See id. at 239. 
reasons, it has largely fallen to the government to protect the environment. Federal environmental statutes exist largely to accomplish that goal.

The extent of regulatory control over the environment is ultimately driven by the value that the nation places on the protection of natural resources. These values can take on a variety of forms, but economists generally place them into two categories: use and nonuse values. ${ }^{93}$ The representative subset of nonuse values-the epitome-consists of benefits derived from public goods that are out of physical reach of the vast majority of the public, but with which individuals nonetheless feel some connection. This portion of a public good's value is the most difficult to estimate and is the focus of the debate over CV. Because nonuse values, as with the measure of pain and suffering, are typically best defined as that element of the total loss not due to use (or inonetary) values, it is important to explore both aspects of environmental loss before moving on to the actual process of ineasureinent.

\section{A. Use Values}

When people directly interact with a natural resource, their decisions implicitly and explicitly represent the use value that they place on that resource. ${ }^{94}$ Under this categorization, as long as the individual uses her five senses to derive value from the environinent, it lias a use value. Included are not only "consumptive" use values such as hunting and logging but also direct and indirect "nonconsumptive" use values such as bird watching and reading about others' use of the resource. ${ }^{95}$ Use values make up a signifi-

93. See, e.g., WARD \& DUFFIELD, supra note 91, at 230. The taxonomy of environmental values is subject to the confusion of any field in which the borders are unclear. The following two Sections make an effort to organize the field in a fashion that presents a representative view of the traditional characterizations. For a more rigorous effort to define a taxonomy, see Alan Randall \& John R. Stoll, Existence Value in a Total Valuation Framework, in MANAGING AIR QUALITY AND SCENIC RESOURCES AT NATIONAL PARKS AND WILDERNESS AREAS 265, 267-68 (Robert D. Rowe \& Lauraine G. Chestnut eds., 1983).

94. See Frank B. Cross, Natural Resource Damage Valuation, 42 VAND. L. REV. 269, 281 (1989); see also Randall \& Stoll, supra note 93, at 266-67 (defining use values as those involving the combination of the existence of the natural resource with any goods or services other than the resource itself). Randall and Stoll's definition of use value encompasses essentially all "uses" of the resource other than mere contemplation of it. Id. at $267-68$.

95. See Steven Edwards, In Defense of Environmental Economics, 9 ENVTL. ETHICS 
cant portion of the value of the most popular natural environments in the country. ${ }^{96}$

Use values are relatively easy to price. ${ }^{97}$ They generally involve "observed choice" 98 or "revealed preferences." For example, individuals purchase hunting and fishing licenses, buy and sell fisl and other sports animals, and travel to get to recreation areas, where they spend money enjoying the land in various ways. Although these transactions do not necessarily convey the full use value that people place in environmental goods, ${ }^{99}$ they do provide a basis for exanimation and extrapolation. When recreational use, for example, is the subject of study, economists can use revealed preference models to determine the dollar value of this sort of coinplex use..$^{100}$ These indirect methods use preferences revealed through consnmer actions (e.g., amounts spent on travel, property, and the avoidance of hazards) to determine the price placed on the use value for certain resources. ${ }^{101}$ As in so many other areas

73, 79 (1987); Randall \& Stoll, supra note 93, at 267.

96. See, e.g., Richard G. Walsh et al., Valuing Option, Existence, and Bequest Demands for Wilderness, 60 LAND ECON. 14, 25 tbl. 3 (1984) (citing a use value as $\$ 58$ million of the $\$ 93$ million total value found).

Demonstrating that different authors approach classification of values in different ways, another commentator discusses values such as "vicarious" use values, which are gained by the knowledge that someone else is going to use the land, separately from use values. See Cross, supra note 94, at 285-86. Holmes Rolston lists among the utility of wildlands their therapeutic value, their cultural, religious, and historic significance, and their role in the development of scientific knowledge and "character" (e.g., the Boy and Girl Scouts). See Rolston, supra note 88, at 27-30.

97. See, e.g., Jerry A. Hausman et al., Assessing Use Value Losses Caused by Natural Resource Injury, in Exxon Symposium, supra note 22, at 342.

98. See Smith, supra note 32 , at 867.

99. Consider the example of national parks, which intentionally set adınission prices low to encourage attendance. See Ohio v. Umited States Dep't of the Interior, 880 F.2d 432, 463 (D.C. Cir. 1989).

100. See Robert Mendelsohn, Assessing Natural Resource Damages with Indirect Methods: Comments on Chapter 8, in VALUING NATURAL ASSETS, supra note 25, at 197, 202. These are "indirect" methods because they consider the actions of consumers, rather than asking them directly about their preferences.

101. See Kenneth E. McConnell, Indirect Methods for Assessing Natural Resource Damages Under CERCLA, in VALUING NATURAL ASSETS, supra note 25, at 153, 162-90 (discussing the hedonic pricing, travel cost, random utility, and averting behavior models of indirect measurements of use value). For a detailed discussion of the use of the "travel cost" method to calculate recreational value, see WARD \& DUFFIELD, supra note 91, at $256-62$.

Contingent valuation (a "direct," as opposed to "indirect," method) also can be used to measure complex sorts of use values. See Department of the Interior, Natural Resource Damage Assessments, 43 C.F.R. \& 11.83(d)(5)(i) (permitting, in the original 
of the law, the calculation of pecuniary values is the most straightforward step.

The next set of environmental values are the so-called "option values," which are often placed into a category between use and nonuse values. Although option values do not involve the immediate use of a natural resource, implicit in their definition is the possibility that the resource may soineday be used. ${ }^{102}$ If the continuing availability of a use value is uncertain, there is a corresponding option value that individuals are willing to pay to retain the option to use that value. ${ }^{103}$ Since continuing availability of environmental resources can be particularly uncertain, option values take on many forms. For example, the value that people place on preserving resources for the use of their children, the "bequest value" of a resource, is an option value. ${ }^{104}$ The common argument for preservation of biodiversity-that unknown or endangered species may contam compounds that would improve human quality of life-rehies on retaiming the option for future use. ${ }^{105}$ In the context of unique environmental resources, option value is particularly relevant since some uses could result in irreversible damage, thereby eliminating the option for the future use of those resources. ${ }^{106}$

DOI regulations, the use of CV for measuring use values); 56 Fed. Reg. 19,772 (1991) (to be codified at 43 C.F.R. 11.83(c)(2)(ii)(D)) (proposed Apr. 29, 1991) (proposing a revised § $11.83(\mathrm{c})(2)(\mathrm{ii})(\mathrm{D}))$ that would retain that permission); WARD \& DUFFIELD, supra note 91 , at $342-44$. In this context, CV is less contentious than when it is used to estimate nonuse values because the CV study can be validated by comparing its results with those of "revealed preference" measures. See 58 Fed. Reg. at 39,351 (1993); 56 Fed. Reg. 19,762 (1991) (discussing why CV estimates of nonuse values are less reliable than those for use values).

102. The potential for future use is not a part of "option existence values"-i.e., the price that an individual would be willing to pay to be able to value the mere existence of a place or species in the future. In general, however, option values involve the possibility of future use, and they are therefore addressed in this Section with other use values.

For a general discussion of option values, see Richard C. Bishop, Option Value: An Exposition and Extension, 58 LAND ECON. 1 (1982); V. Kerry Smith, Nonuse Values in Benefit Cost Analysis, 54 S. EcoN. J. 19, 20 (1987). Option values were first articulated by Burton Weisbrod. See Burton A. Weisbrod, Collective-Consumption Services of Individual-Consumption Goods, 78 Q.J. EcoN. 471 (1964).

103. See Randall \& Stoll, supra note 93, at 267.

104. See, e.g., Note, supra note 27 , at 1981.

105. See Cross, supra note 94, at 286 (calling it "quasi-option value"); Krutilla, supra note 92 , at $780-81$ (discussing option value of genetic variation and other manifestations of option value).

106. Indeed, Kerry Smith indicates that these values are only relevant in the context 
Because it is generally an option for use that is being retained, option values are often considered a subset of use values. At the same time, however, option values are largely noninonetary. Except through donations to environmental and wildlife organizations, people rarely reveal their preference for preserving future uses of natural environments. ${ }^{107}$ Unlike inost use values, then, and like those nonpecumary losses compensated for in personal mjury cases, option values rarely inanifest themselves as revealed preferences. Because of this absence of market activity, option values can generally be estimated only by constructing fictional markets im which one would ask, for example, "If you could pay to ensure the preservation of this prime swimming hole, how inuch would you pay?" This regime of fictional inarkets is the land of contingent valuation. For purposes of looking at the problein of nonuse and nonmarket values in NRD assessment, then, this Note will generally include option values within the range of nonuse values. ${ }^{108}$

\section{B. Nonuse Values}

1. Definitions. If no human were ever perımitted to access or view a wilderness area, individuals might still place some value on the mere knowledge that such a pristine area existed. This nonuse value, felt by the "spiritual descendants of John Muir," would manifest itself as "acute distress and a sense of genuine relative imipoverishment" when natural resources are damaged. ${ }^{109}$ It requires neither contact with the resource in question nor the

of unique resources. See Smith, supra note 102, at 25. Allan Randall and John Stoll disagree, however, and indicate that every environmental resource-even those that are not unique-may have existence value. See Randall \& Stoll, supra note 93, at 268-70.

107. Because of the free rider problein, see supra note 92 , one cannot assume that the level of donations is equivalent to the option value imdividuals place on natural resources.

108. The administrative agencies also group option values with nonuse values. See 56 Fed. Reg. 19,772 (to be codified at 40 C.F.R. $\S 11.83$ (c)) (proposed Apr. 29, 1991) (grouping option values with nonuse values); NOAA Proposed Rules, supra note 8, at 1169 (to be codified at 15 C.F.R. $\S 990.13$ ) (grouping option values with passive use values).

109. Krutilla, supra note 92 , at 779 n.7. Krutilla's article was the first in which existence values were explicitly recognized. His recognition, however, related less to existence as an end in itself than to the option of future use. Although he recognized those who "place a value on the mere existence of biological and/or geomorphological variety and its widespread distribution," id. at 781, he did not appear to put much credence in the utility of holding this value separate from the possibility of use. See id. at $781 \mathrm{n} .11$. 
belief that others will use the resource in the future. ${ }^{110}$ Instead, it is a pure conviction that segments of the natural world should remain unaltered. ${ }^{111}$

Although existence value is not the only type of nonuse value, ${ }^{112}$ its careful segregation from use makes it the quintessential nonuse value. Existence value, therefore, is recognized as "the major element" of nonuse values. ${ }^{113}$ Because its expression also is the most removed from how an economically "rational" individual is expected to behave, existence value has drawn the most attention in assessments of the validity of CV studies.

The heart of that attention has been a debate over the motivation behind existence values that reflects differing views of economists and others regarding the nature of human actions. ${ }^{114} \mathrm{Un}$ -

110. Following this descriptive definition of nonuse values, some economists have defined nonuse values as those values derived from natural resources that are not dependent on any goods rationed by prices. See Randall \& Stoll, supra note 93, at 267-68; Sinith, supra note 14, at 19 . This perspective may be contrasted with another definition that simply classifies nonuse values as those involving anything other than "on site" uses. See Bruce Madariaga \& Kenneth E. McConnell, Exploring Existence Value, 23 WATER RESOURCES RES. 936, 937 (1987) (contrasting Randall and Stoll's perspective on the existence/use value distinction with one in which reading a magazine about another's use of a natural resource would have a nonuse value).

111. As Sagoff describes it, "[M]any Americans oppose the transformation of our most beautiful and expressive landscapes into trailer parks and Shangri-las. They base their opposition, which is sometines fierce, not on an interest in using the areas in question but on a belief that certain areas should be preserved for their own sake." Sagoff, supra note 3, at 1407; see also Thomas C. Heller, The Importance of Normative Decision-Making: The Limitations of Legal Economics as a Basis for a Liberal Jurisprudence-As Illustrated by the Regulation of Vacation Home Development, 1976 WIS. L. REV. 385, 405 ("For soine, a serious loss of well-being . . . results from a broadly held commitment to the normative position that nature is a source of value not because it is used but because it continues to exist.").

112. As noted above, there is an argument that option value and its contained values also should be considered nonuse. See supra note 108 and accompanying text. Furthermore, as the DOI points out in discussing its proposed revised regulations, "there are many categories of nonuse values that have not been consistently defined. Any attempt to categorize explicitly different types of nonuse value would involve arbitrarily selecting a single defimition." 56 Fed. Reg. 19,752, 19,760 (1991). DOI includes existence, bequest, preservation, and intrinsic value within the defmition of nonuse values. Id. NOAA includes bequest, intrinsic, and vicarious values within its proposed definition of nonuse values (which it calls "passive use" values). See NOAA Proposed Rules, supra note 8, at 1073.

113. See, e.g., NOAA Panel Report, supra note 1, at 4602.

114. See, e.g., Edwards, supra note 95 (discussing the alteruative visions of "economic man" and "altruistic man"); Amartya K. Sen, Rational Fools: $A$ Critique of the Behavioral Foundations of Economic Theory, 6 PHIL. \& PUB. AFF. 317 (1977) (critiquing the economic portrayal of man as self-interested and, when making choices based on moral 
der the economists' view, it is assumed that individuals holding existence values are acting "rationally"-i.e. that they derive some self-interested "utility" out of the resource. ${ }^{115}$ From this perspective, existence values are merely the value of "passive uses" of the resource. $^{116}$ So conceived, existence values represent either an "implicit change in [the economic] definition of consumption" that does not involve an actual consumption of the good, ${ }^{117}$ or nothing inore than the value placed on "a very pure public good." Because this conception of behavior retaims the assumptions of economic theory regarding a self-interested motivation, this perspective does not present serious conceptual difficulties for economic valuation.

As Holmes Rolston argues, however, calling nonuse values passive use values inerely creates an economic fiction that forces thein into the "alien reference frame" of a use typology. Saying that these values are passive uses "exactly reverses what those so categorized would say of theinselves: that wildlands are valuable when left alone, apart froin questions of human use."119 The al-

commitment, irrational).

Myrick Freeman argues that the discussion should stop before ever entering this debate. Why bother trying to determine the nature of the motivation, he asks, when all that really matters is whether nonuse values are positive--i.e. whether they exist? Freeman, supra note 25 , at 267 . As is pointed out below, the consensus is that they do. See infra subsection $\mathrm{II}(\mathrm{B})(2)$.

115. See Edwards, supra note 95, at 75-77 (describing the nature of "economic man").

116. See, e.g., NOAA Panel Report, supra note 1, at 4602 (choosing the term "passive use"); NOAA Proposed Rules, supra note 8, at 1073 (same). As the leading case on NRD assessment poimted out, "[o]ption and existence values may represent 'passive' use, but they nonetheless reflect utility derived by humans from a resource, and thus, prima facie, ought to be included in a damage assessinent." Ohio v. United States Dep't of the Interior, 880 F.2d 432, 464 (D.C. Cir. 1989).

117. Smith, supra note 102 , at 20 . Smith seens to have changed his view regarding the nature of consumption in the context of nonuse values, arguing now that consideration of them need not require a redefinition of consumption. See Smith, supra note 14, at 19; see also infra note 118 (assessing one way that existence values could be conceived of without redefining "consumption").

118. Raymond J. Kopp, Why Existence Value Should Be Used in Cost-Benefit Analysis, 11 J. Pol'y ANALYSIS \& MGMT. 123, 124 (1992); see also Kenneth E. McConnell, Existence and Bequest Value, in MANAGING AIR QUALITY AND SCENIC RESOURCES AT NATIONAL PARKS AND WILDERNess AREAS, supra note 93, at 254, 262 (discussing the preferences of the public that create existence value); Milgrom, supra note 30 , at 417. As we have already seen, public goods will generally not be efficiently provided without regulatory intervention. See supra note 92 . This is a flrst small hint about the importance of ensuring that nonuse values are included within NRD assessment.

119. Rolston, supra note 88, at 36 n.11 (addressing the term "off-site users"). Despite 
ternative motivation of Rolston and others, which might be called the "intrinsic" or "altruistic" view of nonuse values, ${ }^{120}$ stands in significant tension with the self-mterested view.

Under the intrinsic view, existence value is dependent not merely on the extent or umiqueness of the physical characteristics of a resource ${ }^{121}$ but on the umique self-identity of every particular resource. ${ }^{122}$ It is a value placed on the "naturalness" of

NOAA's use of the term "passive use," the agency's proposed rules on NRD assessment explicitly recognize that nonuse values include "the value derived from protecting the natural resource for its own sake." NOAA Proposed Rules, supra note 8, at 1169 (to be codified at 15 C.F.R. § 990.13).

120. Economic literature in fact considers "altruistic" and "intrinsic" existence value to be based on two different motivations. See, e.g., Cross, supra note 94, at 290-93 (separately categorizing altruistic existence values and intrinsic values); Madariaga \& McConnell, supra note 110, at 938 (stating that intrinsic existence value is motivated by concern about the state of the world, rather than concern for others). The former is the value one gains from the knowledge that others are benefitting or will benefit from the use of the land, whereas the latter emphasizes the value of nature for its own sake. See Cross, supra note 94, at 292-97 (describing intrinsic values); P.S. Elder, Legal Rights for Nature-The Wrong Answer to the Right(s) Question, 22 OsGOODE HALL L.J. 285, 286 (1984); Rolston, supra note 88, at 30 (discussing the category of "intrinsic moral value").

In practice, however, the two perspectives tend to blend since both stand in contrast to the self-interested motivation described previously. See, e.g., Edwards, supra note 95, at 82 (noting that "ethical views that argue for the intrinsic value or rights of other humans, wildlife, and future generations could be personified by a genuine altruist with unselfish commitments to the well-being of others"). One might even consider "intrinsic" values "altruistic," at least in the sense that they involve altruism with respect to natural resources. In the context of $\mathrm{CV}$, these differently-motivated values are difficult to separate out because neither are traded on markets. But see Madariaga \& McConnell, supra note 110, at 940-41 (making an effort to distinguish between different motivations in a CV study). Because of all these difficulties, this Note also may refer to the values interchangeably.

At the same time, however, there is a critical difference. Like option values, the majority of altruistic existence values are ultimately based on the use of natural resources. Intrinsic values are not, and are therefore the inore natural contrast to self-interested passive use values. It is, therefore, in intrinsic nonuse values that the arguments favoring the incorporation of nonuse values take on their strongest form, and it is this sort of value on which the most compelling reasons for including nonuse values in NRD assessment are based.

121. This characterization is not meant to imply that all existence values are entirely independent of the physical uniqueness of the resource. Option values, altruistic existence values, and to some extent even the intrinsic notion of existence value may be at least partial functions of the physical uniqueness of the resource. Nonuse values "are most significant for irreversible or long-lasting changes to well-known, unique natural resources." 56 Fed. Reg. 19,760 (1991). Nevertheless, they are not limited to such resources. See Randall \& Stoll, supra note 93, at 268-70; NOAA Proposed Rules, supra note 8, at 1152 ("NOAA has found no empirical evidence to suggest that a natural resource must be unique . . . non-reproducible and/or permanently injured in order to have significant passive use values.").

122. As the court in Ohio v. United States Dep't of the Interior, 880 F.2d 432 (D.C. 
those resources that we perceive as untouched by humans. ${ }^{123}$
This perception of naturalness ${ }^{124}$ is, as Carol Rose puts it, de-

Cir. 1989), noted, Congress's reliance on restoration costs was based on a realization that natural resources are not fungible goods. Id. at 456 . This asymmetry between resources must be based on something more than the trivial physical differences between a site and its "restored" version; the asymmetry must be found in the intrinsic value that individuals place on particular resources and their naturalness.

We would not say that one person can "replace" another. For example, the pain from the loss of a child is not assuaged for those parents who lave another. We could not "compensate" parents for the loss of their child by providing them with a substitute child. Only if we think of people as commodities can we make this sort of exchange, and we do not think of individuals in that way. See Radin, supra note 31, at 1905-06, 1925 (discussing arguments against commodification of the person in general and baby-selling in particular). Nonetheless we compensate parents for their loss.

In a similar way, mere "restoration" of a natural resource does not "restore" the value of the damaged resource. Such a view improperly makes natural resources fungible. John Daum, for example, simply ignores the extent to which the value that we place on resources depends on their individual uniqueness. He states that, since "[e]xistence value reflects the value ... of the fact that a resource is in existence[,] there should be no impairment of this value if the resource is restored," Daum, supra note 27 , at 399 , and lie repeats the clain for option and bequest values. Id. He does not see that there is no restoring "the resource," much as there is no restoring "the child." The nonuse values that lie wants to ignore are not part of the market systein, are not compensated for by the plysical "restoration" of a resource, and yet are largely what make natural places, organisnıs, and relationslips important to us. Cf. Radin, supra note 31, at 1884-86 (arguing that the maintenance of noncommodifiable objects is critical to "human flourishing").

123. For one view of what "naturahress" means, and an apocalyptic vision of what is happening to "natural" places in a world threatened by global climatic change, see BILI MCKIBBEN, THE END OF NATURE (1989). McKibben argnes that the pervasiveness of human activities on the planet las an impact on every possible resource. As a result, there are no longer places to which an individual can go to feel alone, to feel like lumanity is not intruding. Because such feelings are integral to our idea of what "nature" is, argnes McKibben, nature itself has essentially been eliminated. But see infra note 124 (outlining the argument that this sense of nature is naive).

A classic example of the inportance of naturalness in resources and the inadequacy of replacement is that of the "plastic trees." Mark Sagoff and Laurence Tribe wondered whether trees of plastic made to match real trees in every way would be identical for purposes of a utilitarian calculation. Both concluded "no," arguing that plastic trees would not capture the full range of values held in the original. The difference is the existence value of the original, "natural" tree. Mark Sagoff, On Preserving the Natural Environment, 84 YALE L.J. 205 (1974); Laurence H. Tribe, Ways Not to Think About Plastic Trees: New Foundations for Environmental Law, 83 YALE L.J. 1315 (1974).

124. Critics of McKibben and others have argued that this sense of nature is naive. See, e.g., Cross, supra note 27, at 334-35 (stressing that "nature" is an ever-changing "kaleidoscope" rather than a single pristine state); Lynn Margulis \& Edwin Dobb, Untimely Requiem, THE SCIENCES, Jan.-Feb. 1990, at 44, 47 (reviewing MCKIBBEN, supra note 123, pointing out that humans have been influencing ecosystenis on regional and global scales for millions of years and arguing that a view of nature founded in a notion of an unclianging "natural" state is simply "bunkum"). Logical naivete, lowever, does not alter the importance of this view of nature to the issue of existence value. We often 
rived from the deep ecology movement and based on "kinshiptalk," not "preference-talk."125

Existence values spurred by non-self-interested motivations are difficult for economic models to mcorporate. Individuals gain no benefit from the values and thereby act agamst the "rational" preference model of traditional economics. ${ }^{126}$ The values "drive[] a wedge between personal choice and personal welfare, and much of traditional economic theory relies on the identity of the two." As for any portion of nonuse values based in an "altruistic" perspective, they may not be included because they "double count" benefits that others receive $e^{128}$ and thereby skew the analysis. For many economists, attempting to measure such values through $\mathrm{CV}$ deviates from appropriate economic modelling.

Self-interested values, intrinsic values, and the tension between thein he at the heart of the struggle over contingent valuation.

value goods based merely on our opinions and beliefs, even if those beliefs are not founded in rigorous logic or scientific fact. (Consider, for example, the money donated to churches as a weekly tithe.) For all their fiaws, those values are no less important than those deriving their weight from a more "rational" belief. Even if the general perception of nature is not rigorously justifiable, then, the value individuals place on seemingly "natural" resources is still entitled to economic and policy recognition.

125. Carol M. Rose, Environmental Faust Succumbs to Temptations of Economic Mephistopheles, or, Value by Any Other Name Is Preference, 87 MicH. L. REV. 1631, 1644 (1989) (reviewing MARK SAGOFF, THE ECONOMY OF THE EARTH (1988)).

This focus on existence value may link rights for the environment too closely to human values for most deep ecologists. A reformulation of this definition of nonuse values a la Christopher Stone might be more appealing because it would place these values in the hands of the resources themselves, rather than making their existence depend on humans. See, eg., Christopher D. Stone, Should Trees Have Standing?-Toward Legal Rights for Natural Objects, 45 S. CAL. L. REV. 450, 475-76 (1972) (describing intrinsic, nonuse-hike values from the perspective of the resource).

126. See Edwards, supra note 95, at 82-83; see also infra subsection III(B)(2) (regarding the criticisms of CV targeted at the irrational nature of interviewee decisions).

127. Sen, supra note 114 , at 329.

128. See Milgrom, supra note 30 , at 420 . Milgrom argues just this-that including altruistic values double counts those values held by others. For altruistically motivated existence values such as bequest value, this claim may be true. His point, however, suffers from the fact that the altruism being measured is not exclusively, or even mostly, altruisin based either explicitly or implicitly on benefits enjoyed by another individual. Instead, altruism (in the form of intrinsic values) may be felt for the imjury to the environment itself, which has no other representation in the cost-benefit assessment analysis. Nothing in economic analysis should preclude consideration of a unique value held by an individual who happens to be dependent on the "well-being" of an object that is not an actor for purposes of the economic analysis. See also Madariaga \& McConnell, supra note 110, at 941 ("Making existence value contingent on altruism" imposes a faulty structure on cost-benefit analysis, but "[e]xistence value which stems from intrinsic motives... has an unambignous effect on the measurement" of nonuse values.). 
Frustratimgly, the real motivation behind existence value, and in fact all nonuse value, is probably some combination of all these stimuli. ${ }^{129}$ Moreover, these two perspectives may not describe different values as much as they describe two different ways of interpreting the same value. Economics therefore faces a dilemma: should it risk contaminating the analysis with altruistically motivated nonuse values or should it disregard nonuse values altogether and risk the effect of ignoring what may be a substantial part of the value individuals hold in natural resources? ${ }^{130}$ Although either route is possible, both threaten the integrity of the process.

In the context of the environmental statutes governing NRD assessment, the decision between the threats is a political and legal one. ${ }^{131}$ Critics of $\mathrm{CV}$ have argued that the threat of "contaminated" analysis is greater than the threat of ignoring nonuse values. The remaming Parts of this Note argue that the former threat is inuch less, ${ }^{132}$ and the latter much greater, ${ }^{133}$ than the critics believe. The resolution of the dilemma should permit analytical uncertainty in the name of ensuring legal, economic, and environmental stability. As in the tort system, any uncertainty that renams part of the valuation must simply be accepted as the price of including nonuse values in legal analysis. The decision whether to use an imperfect means of valuation cannot wait until the academic commumity has resolved its debate over the validity of those methods. As the next subsection points out, there are values to be

129. See Edwards, supra note 95 (contrasting the views of economic and altruistic man); Smith, supra note 102 , at 20 (noting that existence value may be explained by both indirect use and altruistic models); see also Mark Sagoff, Environmental Economics: An Epitaph, RESOURCES, Spring 1993, at 2, 4 (noting the complex factors accounting for preference decisions).

130. See Sagoff, supra note 129, at 5.

131. The importance of political decisions is recognized even by critics of econounic valuation, who have concluded that such valuation can inform the political process. These authors' main objection is that economic valuation can never establish the "true value" of environmental losses. See Milgroin, supra note 30, at 418; Sagoff, supra note 3, at 1393, 1409 (noting that economics might play a useful role in informing political analysis). As noted above, however, in the context of tort verdicts, very few individuals think that pain and suffering awards are the "true value" of the loss. See supra note 83 and accompanying text. Sinilarly, the measurement of nonuse values does not give a "true value" of the environmental loss. It is merely an estinate, and any dangers stemming from the imperfection and imprecision of that estimate are outweighed by the political and legal necessity of including nonuse values in our measure of loss.

132. See infra Section III(B).

133. See infra Part IV. 
considered, and as long as we have an acceptable (although imperfect) method for translating those values into economic prices, ${ }^{134}$ we are free to conclude that such a inethod should be used as a means of guaranteeing that society is reinbursed for the full extent of the environmental losses it suffers.

2. The Positive Value of Existence and the Difficulties of Assessment. Nonuse values do exist and they do have a positive price. ${ }^{135}$ As one author points out, "[t] he strongest argument for including existence values [in NRD assessment] is that they indubitably exist."136 Another commentator, after reviewing twelve CV studies, noted that, despite questions regarding the precision of the studies, they do "provide substantial support for the hypothesis that nonuse values ... are positive." $" 137$ The NOAA Panel "start[ed] from the premise that passive-use loss-interim or permanent-is a meanimgful component of the total dainage resulting from environmental accidents." ${ }^{\text {"138 }}$ Even some critics grant that the magnitude of nonuse values is "often positive."139 The few examples of revealed preferences regarding nonuse values support the conclusions of the CV studies and our own intuition. Consider, for example, the millions of individuals who donate to environmental organizations with the intent of protecting species that the donors may never see. ${ }^{140}$ Despite the solnewhat uncertain character of existence value, it is an important part of resource values.

Unfortunately, just as with nonpecuniary losses in tort cases, the absence of a "behavioral trail" associated with nonuse values inakes thein extreinely difficult to ineasure. ${ }^{141}$ Inherent in the no-

134. As $\mathrm{I}$ argue below, $\mathrm{CV}$ is such a method and does provide valuable information. See infra Section III(B).

135. Although not necessarily every individual holds positive nonuse values, the vast majority of us do, see supra note 7 , and there is hittle debate that, in the aggregate, nonuse values are positive.

136. Cross, supra note 94 , at 286.

137. Freeman, supra note 25 , at 297.

138. NOAA Panel Report, supra note 1, at 4610.

139. See, e.g., Shavell, supra note 27 , at 381 .

140. See Freeman, supra note 25 , at 287 ; Krutilla, supra note 92 , at 781 . Freeman recognizes that the true level of nonuse values is probably significantly higher than is revealed through such donations: "[I]f 'free-rider' behavior is significant, these donations would be only a lower bound of true aggregate willingness to pay for preservation. . . . [A]ggregate nonuse values are likely to be larger, and perhaps very much larger, than observed acquisition and advocacy expenditures." Freeman, supra note 25, at 287-88.

141. See NOAA Panel Report, supra note 1, at 4610. 
tion of nonuse values is the lack of a direct relationship between an individual and the resource. Because preferences are not revealed through the market, or even through forced decisionmaking (e.g., whether to stay home and work or to take a vacation and go hiking), it is particularly difficult to apply traditional pricing methodologies to the value.

An additional problem with the pricing of nonuse values is the difficulty that individuals face in trymg to value their own preferences. "[A]s values grow intangible," Rolston points out, "the individual's capacity to price them becomes progressively poorer." ${ }^{142}$ Without the experience of market trading, most individuals have a difficult time translating values into prices-if they can even conceive of the values as solnething transferrable into dollars. Individuals asked to put a price on these values "are unaccustomed to citizen 'purchases' of genetic diversity, wildlife encounters, scenic vistas, or wild cultural symbols, especially on lands that the citizens already own and in situations where no inoney changes hands." 143 In CV studies, soine individuals may coinpletely reject the imphicit equivalence of economic and environinental values by providing a "protest bid"-argumg that they would be willing to pay either nothing or everything for the environmental good in question. ${ }^{144}$

This unwillingness and mability to place values on an economic scale is the classic problem of incommensurability. For soine, this incommensurability means that the effort to price nonuse values cannot and should not be done. ${ }^{145}$ But these values do exist, and federal statutes and regulations governing recovery for NRDs recognize them. In a legal systen in which the basic language is cash, an expression to the court of the "pricelessness" of a resource or the "deep anguish" associated with its loss or despoilment inay draw sympathy but will not result in recovery. Recovery under this system requires something niore than plat-

142. Rolston, supra note 88 , at 35 .

143. Id.

144. See Sunstein, supra note 29 , at 36 ; see also Rolston supra note 88 , at 34 ; Sagoff, supra note 3, at 1396-99 (outlining societal "protest bids" in the form of absolutist or merely economically inefficient statutes).

145. See Rolston, supra note 88, at 38 (arguing, froin an environmentalist's perspective, that pricing existence values is a category mistake); Rosenthal \& Nelson, supra note 30, at 116-18 (arguing, from a conservative point of view, that dollar estimates of existence value inean little in a world where values constantly change). 
itudes; it needs a consistent method for assessing all forms of environmental loss.

\section{ASSESSING NONUSE LOSSES: ThE STATE OF CONTINGENT VALUATION}

Correctly implemented, the NRD recovery provisions of the federal environmental statutes will prevent polluters from escaping liability for the full impact of the mjuries they cause to the environment. The heart of the implementation is the statutory and regulatory regime for assessing NRDs. Recognizing the importance of complete liability for resource damages, the agencies charged with the implementation and enforcement of the statutes liave concluded that the statutes require that both use and nonuse values be recoverable. Recent critics have targeted tliat conclusion because they believe thiat the only existing means of assessing nonuse values, contingent valuation, is economically and legally useless. In light of recent work by economists, this assertion cannot be mamtained. ${ }^{146}$ Furthermore, a reasonable examination of existing goals and demands of the legal system fully supports the conclusion that $C V$ can and should be a part of NRD assessment. ${ }^{147}$ Understandimg the criticisms and the ultimate validity of $\mathrm{CV}$, however, must begin with a look at the place that $\mathrm{CV}$ and nonuse values have in the full regime of NRD assessinent.

\section{A. Statutory and Regulatory Provisions}

1. Statutory Language. Although the three statutes that permit NRD recovery address different environmental probleins, the basic structure of an NRD recovery action is the same under all three. As an example, consider the derailment of a railroad car that spills a pesticide into a mountain stream, killing nearly every plant and animal closely associated with it. ${ }^{148}$ Under CERCLA, ${ }^{149}$ the company responsible for the spill inust pay both to

146. See infra Section III(B).

147. See infra Part IV.

148. This scenario is essentially what happened to the Upper Sacramento River in July 1991. See Jenifer Warren, Spill Turned Sacramento River into a Graveyard, Scientists Say, L.A. Times, July 28, 1991, at A1. It also resembles one of the few cases that has directly addressed the use of nonuse values in a CERCLA action. See Idaho v. Southern Refrigerated Transp., No. 88-1279, 1991 WL 22479 (D. Idaho Jan. 24, 1991).

149. CERCLA, 42 U.S.C. $\$ \S 9601-75$ (1988), governs damages due to the release of 
clean up the spill and for the loss of the natural resources. The NRDs may be recovered only by a "trustee" of the resource, which would include any state, federal, tribal, or foreign government that owns or controls ${ }^{150}$ the stream, plants, and animals. In this case, lost use values might include damages from lost fisheries or tourisin. Lost nonuse values might include the value individuals place on the pleasure of living in the midst of a vital, growing environment, on the knowledge that one could enjoy the stream if one wanted, and on the mere existence of the fish, plants, trees, and a healthy, vibrant ecosystein.

Natural resource dainage recovery in the United States can be traced to the CWA, ${ }^{151}$ but it is in CERCLA and the OPA that NRD recovery has coine into its own. ${ }^{152}$ Both of these statutes are more explicit than the CWA regarding the nature of both recoverable injuries and the assessment process. Under both CERCLA and the OPA, responsible parties are liable for "damages for injury to, destruction of, or loss of" natural resources. ${ }^{153}$

hazardous substances other than oil. Damages from oil spills are governed by the Clean Water Act (for spills prior to August 18, 1990) and the Oil Pollution Act (for spills occurring on or after August 18, 1990). See WARD \& DUFFIELD, supra note 91, at 65 .

150. A trustee may recover for natural resources "belonging to, managed by, held in trust by, appertaining to, or otherwise controlled by" a government. 42 U.S.C. $\$ 9601(16)$ (1988) (defining "natural resource" under CERCLA); 33 U.S.C. § 2701(20) (Supp. IV 1992) (defining same under the Oil Pollution Act); see also 56 Fed. Reg. 19,752, 19,761 (1991) (noting that the language of the statute ensures "a wide range of legitinate government interest in natural resources that may . . . be held in private ownership"); Lutz v. Chromatex, Inc., 718 F. Supp. 413, 419 (M.D. Pa. 1989) (noting that state-controlled water supphies are natural resources under CERCLA).

151. See WARD \& DUFFIELD, supra note 91 , at 66 . The Clean Water Act provides that a federal or relevant state goverument may recover "any costs or expenses imcurred .... in the restoration or replacement of natural resources dainaged or destroyed as a result of a discharge of oil or a hazardous substance in violation of [the Act]." 33 U.S.C. $\S 1321(f)(4)$ (1988). Funds recovered must be used "to restore, rehabilitate, or acquire the eqnivalent of such natural resources." Id. § 1321(f)(5). According to the legislative history, when the "damaged or destroyed resource is irreplaceable[,] . . the measure of liability is the reasonable cost of acquiring resources to offset the loss." H.R. CONF. REP. No. 830, 95th Cong., 1st Sess. 92 (1977), reprinted in 1977 U.S.C.C.A.N. $4424,4467$.

152. Any spill of oil or a hazardous substance in water or any spill of a hazardous substance on land occurring after 1990 is covered by either CERCLA or the OPA. See supra note 149.

153. 42 U.S.C. \& 9607(a)(1)-(4)(C) (1988) (CERCLA); 33 U.S.C. $\S 2702(b)(2)(A)$ (Supp. IV 1992) (OPA). The OPA permits recovery for damages for the "loss of use of" natural resources, but the legislative history indicates that this language does not necessarily limit recovery to "use values." See S. REP. No. 94, 101st Cong., 1st Sess. 15 (1990), reprinted in 1990 U.S.C.C.A.N. 722, 736-37 (providing, for example, that the value 
The damages may be used to fund the restoration, rehabilitation, or replacement of natural resources, or the acquisition of equivalent natural resources. ${ }^{154}$

The most important provisions in the statutes are those governing the nature of NRD assessment. The language in CERCLA explicitly requires that "[ $t]$ he measure of damages ... shall not be limited by the sums which can be used to restore or replace such resources." 155 In the few cases that have detailed the nature of the losses compensable under this section, ${ }^{156}$ courts have included aesthetic and existence values among recoverable losses. ${ }^{157}$ Similarly, the OPA provides that the measure of natural resource damages is:

(A) the cost of restoring, rehabihitating, replacing, or acquiring the equivalent of, the damaged natural resources;

(B) the diminution in value of those natural resources pending restoration; plus

(C) the reasonable cost of assessing those damages. ${ }^{158}$

Both statutes are also notable for their requirements regarding the promulgation of NRD assessment methods by federal agencies. ${ }^{159}$ Although their presence is remarkable in contrast to the CWA (which contamed no requirement for assessment methodology rules), the OPA regulations are relatively unexceptional, merely delegating the responsibility for the promulgation to NOAA. ${ }^{160}$

of sea otters is more than the value of their pelts).

154. See 42 U.S.C. \& $9607(f)(1)$ (mentioning all but "rehabilitation" under CERCLA); 33 U.S.C. \& 2706(c)(1)(C) (Supp. IV 1992) (under the OPA).

155. 42 U.S.C. \& 9607(f)(1); see also id. \& 9651(c)(2).

156. "There continue to be very few cases involving nonmarket valuation which have actually been ruled on by the courts as opposed to settled out of court." John Loomis \& Peter Anderson, Idaho v. Southern Refrigerated, in WARD \& DUFFIELD, supra note 91, at $389,390$.

157. See Ohio v. United States Dep't of the Interior, 880 F.2d 432, 464 (D.C. Cir. 1989); In re Acushnet River \& New Bedford Harbor Proceedings, 716 F. Supp. 676, 686 (D. Mass. 1989) (considering aesthetic values). The court in Acushnet also noted the possibility that "existence' and 'intrinsic' values attributable to natural resources" may be diminished and implied that such values may be a basis for recovery. Id. at $686 \mathrm{n} .15 ; c f$. Idaho v. Southern Refrigerated Transp., No. 88-1279, 1991 WL 22479, at *18-19 (D. Idaho Jan. 24, 1991) (rejecting CV evidence of existence value in this case, although "not mean[ing] to suggest that the steelhead had no existence value").

158. 33 U.S.C. \& 2706 (d)(1).

159. See 42 U.S.C. §§ 9651(c)(1)-(2); 33 U.S.C. \& $2706(e)(1)$.

160. 33 U.S.C. $\S 2706(\mathrm{e})(1)$ (also requiring NOAA to consult with the EPA and the Fish and Wildlife Service). Nonetheless, NOAA has conducted a detailed rulemaking process and pronulgated a set of proposed rules that are substantially similar to those pro- 
In contrast to the OPA, the CERCLA provisions are quite detailed. The statute requires the regulations to include "type $A$ " procedures for "simplified assessments requiring minimal field observation" and alternative "type B" protocols "for conducting assessinents in individual cases to determine the type and extent of short- and long-term imjury, destruction, or loss."161 Type B methods, which presently govern the use of $\mathrm{CV}$, were intended to "identify the best available procedures to determme such dainages, including both direct and indirect injury, destruction, or loss and ... take into consideration factors including, but not limited to, replacement value, use value, and ability of the ecosystein or resource to recover." ${ }^{162}$ The responsibility for promulgating the regulations for CERCLA, which also will apply to the remaining damage assessments under the $\mathrm{CWA}^{163}$ was delegated to the Department of Interior (DOI). After some delay, the regulations were issued in $1987 . .^{164}$ Under both the OPA and CERCLA, trustees need not use the recommended methodology to assess NRDs, but those who do enjoy a "rebuttable presumption" that their estimate of damages is correct. ${ }^{165}$

posed by the Department of Interior (DOI). See NOAA Proposed Rules, supra note 8, at $1069-71$.

161. 42 U.S.C. \& 9651(c)(2). The streamlined computer modelling approach of the type A methods will be of the most use when the impact is minor. See Natural Resource Damage Assessments, 58 Fed. Reg. 39,328, 39,329 (1993) (noting that a Great Lakes model is in progress); Ohio, 880 F.2d at $484-85,487$ (describing the original computer model and discussing legislative intent regarding the scope of type A regulations); WARD \& DUFFIELD, supra note 91 , at 157 . Since minor releases will be more common than major ones, type A methods will ultimately be the most heavily utilized. See infra text accompanying notes $275-79$. It is, nonetheless, the more complex type $B$ rules that have drawn the most attention. Not only does their more flexible approach to assessment reflect underlying assumptions about the propriety of assessing nonuse values, but the cases that they will be applied to are the ones in which the most will be at stake. The proposed NOAA regulations conceive of a sinilar division of methodologies into simple and complex types. See NOAA Proposed Rules, supra note 8, at 1067-68 (describing four basic methods for NRD assessment, of which two are relatively simple, one intricate, and one of intermediate complexity).

162. Id; see also Ohio v. United States Dep't of the Interior, 880 F.2d 432, 464 (D.C. Cir 1989) (noting that this language "is expressly not limited to use value; if anything, the language inplies that DOI is to include in its regulations other factors in addition to use value"); id. at 478 (sustaining $\mathrm{CV}$ as a "best available procedure").

163. See 42 U.S.C. $\& 9651(c)(1)$.

164. See 43 C.F.R. pt. 11 (1992).

165. 42 U.S.C. $\$ 9607(\mathrm{f})(2)(\mathrm{C})$ (applying rebuttable presumption to uses of developed methodology in both CERCLA and the CWA); 33 U.S.C. $\$ 2706(\mathrm{e})(2)$ (OPA). 
Although trustees may enjoy a "rebuttable presumption," the agencies promulgating the regulations were not so lucky. Soon after DOI issued its first set of rules, they were challenged in the U.S. Court of Appeals for the District of Columbia Circuit by states, environmental groups, and industries. In response to the court's ruling in that case, ${ }^{166}$ DOI has had to revise the regulations. ${ }^{167}$ NOAA has simultaneously been developing its own set of regulations for the OPA, and the agencies have been working together in the developinent of their respective regulations. ${ }^{168}$ This effort to standardize the procedure for NRD assessment has been a hightnimg rod for debates over the role of nonuse values and contingent valuation in NRD cases. ${ }^{169}$

166. See Ohio, 880 F.2d at 481 .

167. For a further discussion of the DOI regulations (both old and new), see infra subsectiou III(A)(2).

168. See Natural Resource Damage Assessments, 58 Fed. Reg. 39,328, 39,333 (1993) (noting that the DOI "will continue to coordinate its rulemakings with those of NOAA"); NOAA Proposed Rules, supra note 8, at 1069 (noting that NOAA is doing the same with DOI).

169. Some commentators have pointed out that the DOI regulations will likely become "a sort of primer or scientific evidentiary manual instructing federal judges on how to understand and apply complex technical natural resource injury assessment methodologies." Anderson, supra note 35, at 26, 47-48; see also Howard Kenison, Uncertain Legal lssues: Comments on Chapter 3, in VAIUING NATURAL ASSETS, supra note 25, at 63,72 . This observation is true for several reasons. First, the regulations represent a long process of careful scholarly consideration regarding the appropriate methods for NRD valuation. The results, especially for the more complex type $B$ regulations, are supposed to represent the "best available procedures" for determining damages. See 42 U.S.C. § 9651(c)(2) (1988). Second, in addition to their intellectual value, the proposed rules are likely to be at the center of almost any attempt at NRD recovery. Despite the voluntary nature of the rules, any state that launches into the field of NRD assessment without relying on them will face a much more difficult case than if it remained true to the regulations. One barrier is the loss of the rebuttable presumption gained by following the rules. A second is the evidentiary implication: if the regulations represent the "best available procedures," what does that say about procedures that do not comport with the regulations? Facing damage estimates prepared on the basis of those regulations and the congressionally mandated "rebuttable presumption" they carry, judges will have little choice but to turn to the regulations and regulatory history in an effort to judge the value and validity of the evidence. See infra subsection $\operatorname{III(B)(3)~(discussing~bow~judges~will~resolve~}$ the evidentiary issues in such an event).

NOAA and DOI also intend to develop a guidance document to direct the use of $\mathrm{CV}$ as a means of estimating nonuse values. See NOAA Proposed Rules, supra note 8, at 1147. The administrative and intellectual weight behind such a jointly issued document would ensure that judges would give it great weight when evaluating the use of $\mathrm{CV}$ in an NRD case. 
2. DOI Regulations Governing NRD Assessment and Ohio v. United States Department of the Interior. The regulations issued by DOI in 1986 and $1987,{ }^{170}$ the court case challenging those rules, ${ }^{171}$ and the subsequent proposed revision ${ }^{172}$ present a microcosm of the debate over nonuse values. The case at the center of this debate, Ohio v. United States Department of the Interior, was filed with the U.S. Court of Appeals for the District of Columbia Circuit soon after the mitial promulgation of the regulations. ${ }^{173}$ Several states, environmental organizations, and industry representatives challenged those regulations as unreasonable interpretations of the statute. The foci of the debate were three regulatory presumptions that governed the appropriate ineasure of damages (restoration or diminished use), ${ }^{174}$ the types of values that should be considered in that measurement (use or nonuse), ${ }^{175}$ and the nuethodologies that should be used to estimate those values (nrarket price or CV, for example). ${ }^{176}$

The first presumption with respect to the ineasure of damages required that the trustee select the lesser of 1) restoration or replacement costs or 2) diminution of use values as the basis for the injury. ${ }^{17}$ In Ohio, the court struck down this provision as improperly iguoring congressional intent that the basic neasure of NRDs be restoration value. ${ }^{178}$ In place of this "lesser of" rule, DOI's proposed revised regulations use "compensable value" as a basis for recovery. ${ }^{179}$

170. Natural Resource Damage Assessments, 43 C.F.R. pt. 11 (1987) (type A regulations); Natural Resource Damage Assessments, 43 C.F.R. pt. 11 (1986) (general provisions and type $B$ regulations).

171. Ohio v. United States Dep't of the Interior, 880 F.2d 432 (D.C. Cir. 1989).

172. Natural Resource Damage Assessments, 56 Fed. Reg. 19,752, 19,767 (1991) (to be codified at 43 C.F.R. pt. 11) (proposed April 29, 1991).

173. The NRD rules contained expedited type $A$ assessment methodologies as well as more complex type B processes. The Ohio decision addressed the rules goveruing the latter, whereas a simultaneous case, Colorado v. United States Dep't of the Interior, 880 F.2d 481 (D.C. Cir. 1989), challenged the type A methodologies.

174. Ohio, 880 F.2d at 441.

175. Id. at 462 .

176. Id.

177. Natural Resource Damage Assessments, 43 C.F.R. $\S 11.35(b)(2)$ (1989).

178. Ohio, 880 F.2d at 459.

179. Natural Resource Damage Assessments, 56 Fed. Reg. 19,752, 19,768 (1991) (proposing a revised 43 C.F.R. $\S 11.81$ (a), which called for assessment of compensable value, as defined in proposed 43 C.F.R. $\$ 11.83$ (c), to include both use and nonuse values); see also NOAA Proposed Rules, supra note 8, at 1181 (proposed 15 C.F.R. § 990.77, calling 
The second and third presumptions were contained within the hierarchy of assessment models outlined in section 11.83(c) of the rules. Under this hierarchy, the best means of estimating losses was to rely on the market price of use values. Nonuse values and nonmarket methods of valuation like $\mathrm{CV}$ were permitted only when the more preferred method or value was impossible to use. ${ }^{180}$

The Ohio court also struck down this "hierarcliy of values." Recognizing the way in whicl the type of value to be considered was governed by the valuation metlodology, the court rejected the step-by-step process required by the regulations. ${ }^{181}$ "[R]esources have values that are not fully captured by the inarket system," the court noted, and the requirement that only market value be used to assess those values departed from that view. ${ }^{182}$ Permitting nonmarket methods to be used only when the resource's use values are not ascertainable was unduly restrictive because having market value does not preclude the resource from also having nonmarket value. ${ }^{183}$ Neither the statute nor congressional intent permitted this hierarchy of assessment favoring use values. ${ }^{184}$ The court's reading of the statutory mandate is unambiguous: values otlier than "use values" slould be considered in the assessment methodologies. ${ }^{185}$ Option value is clearly included under either of the court's notions of nonuse values, and existence value is also either a "passive use" or a factor "not limited to use value."

for assessment of compensable value, as defined to include both use and passive use values).

180. Natural Resource Damage Assessments, 43 C.F.R. \& 11.83(b)(2) (1989) (permitting nonuse analysis only if use values could not be determined); Natural Resource Damage Assessments, id. \& 11.83(d)(5)(ii) (permitting CV analysis of nonuse values only when use values could not be determined).

181. Ohio, 880 F.2d at $462-64$.

182. Id. at 463.

183. Id.

184. Id.

185. Id. at 464. ("Option and existence values may represent 'passive' use, but they nonetheless reflect utility derived by liumans from a resource, and thus, prima facie, ought to be included in a damage assessínent.").

186. Id. Unfortunately, the court's extension of its analysis to nonuse values reveals a somewhat confused characterization of those values. It first required DOI to include "non-consumptive values, such as option and existence values, in the calculation of use values," id., thereby implying that these values should be considered use values. It then rejected DOI's argument that such values need not be included since \& 301(c) "mentions only use values." Id. As the court correctly pointed out, the statute in fact says that the methodologies "sliall take into consideration factors, including, but not limited to . . . use 
This more complex view of the nature of values is encompassed in the proposed revised DOI regulations under the rubric of "coinpensable value," which is a combimation of use and nonuse values. ${ }^{187}$ Although the assessinent methods used must be justified and the costs inust remain "reasonable" compared to the level of damages, ${ }^{188}$ a trustee may use any of the many alternative methodologies to estimate the range of values contained within "coinpensable value."

If a trustee seeks to recover for nonuse values (as it almost certainly will), the absence of other useful methodologies means that it inust turn to $\mathrm{CV}$ to estimate those values. ${ }^{190}$ The DOI regulations governing the use of $\mathrm{CV}$ were upheld by the Ohio court as reasonably representing the "best available procedure"191 but have nonetheless been under review by DOI because of both the level of debate that has been engendered regarding CV's use and the ongoing review regarding that use that has been taking place at NOAA. ${ }^{192}$

\section{B. The Nature and State of Contingent Valuation}

1. General Concepts. Contingent valuation can be used to ineasure any economic value. It is "the most flexible of the valuation techriques" available to economists and, in the context of

value" and implies that additional values should be included. Id. The court thereby suggests that option and existence values are not use values, but it then asks why they should not be considered "use values," even under DOI's interpretation of the statute, since "[o]ption and existence values may represent 'passive' use, but they nonetheless reflect utility derived by liumans from a resource." Id.

187. Natural Resource Damage Assessments, 56 Fed. Reg. 19,752, 19,772 (1991) (to be codified at 43 C.F.R. $\S 11.83$ (c)) (proposed Apr. 29, 1991).

188. See id. at 19,756 (referring to the Compensation Determination Plan and the requirement that the trustee "give a brief rationale for the clioice of . . the inethodologies used to estinate ... the compensable value"); $i d$. at 19,754 (noting the requirement that the cost of the assessment be reasonable as compared to the "anticipated amount of damages to be recovered").

189. See id. at 19,759 .

190. "[Contingent valuation] is the only nonmarket valuation metlodology currently available that is capable of explicitly estinating nonuse values." Id; see also NOAA Proposed Rules, supra note 8, at 1142.

191. Ohio v. United States Dep't of the Interior, 880 F.2d 432, 476-78 (D.C. Cir. 1989). Ohio upleld DOI's decision to include CV in the NRD assessment methodologies as "intelligent" aud "cautious," $i d$. at 476 , "reasonable and consistent with congressional intent," id. at 477 , and fairly representing the "best available procedure," id. at 478.

192. See Natural Resource Damage Assessments, 58 Fed. Reg. 39,328, 39,351-52 (1993) (discussing the DOI evaluation of CV and nonuse values). 
NRD assessment, to natural resource trustees. ${ }^{193}$ It is also the only way of explicitly measuring nonuse values. ${ }^{194}$

The metlod's name comes from its premise and underlying structure. By setting up a "contingent market" for a particular resource and querying imdividuals witl a carefully designed and administered survey about low they would act in such a market, $\mathrm{CV}$ measures the value that people would place on goods bought and sold there. It is a "direct" method of assessment ${ }^{195}$ that asks people what the value of a resource is. Its roots lie in the idea that conversation is the best way to discover an individual's true preferences. ${ }^{196}$

In the context of market values, this method poses few problems because it essentially mimics real world purchases and because other metliods can be used to clieck the validity of $\mathrm{CV}$ results. ${ }^{197}$ As use values become increasingly separated from inarkets, lowever, the complexity of questions and the care with which they are administered must increase. The pinnacle of difficulty is reaclied with nonuse values: they liave no corresponding market, so CV markets look like nothing famikar to the survey designer;

193. Richard C. Bishop \& Thomas A. Heberlein, The Contingent Valuation Method, in WARD \& DUFFIELD, supra note 91, at 281, 283.

194. See Natural Resource Damage Assessments, 56 Fed. Reg. 19,752, 19,759 (1991) (to be codified at 43 C.F.R. \$11) (proposed Apr. 29, 1991).

Some have argued, however, that this is not quite the case. See Cross, supra note 27, at 333 ("[R]estoration can itself embrace the non-use values and capture them better than contingent valuation."); Daum, supra note 27, at 397-99. Restoration cost, they claim, implicitly includes nonuse values since it "replaces" the resource in which individuals had existence, option, or bequest value. See Cross, supra note 27, at 333; Daum, supra note 27, at 398. As I argue above, however, see supra note 122, a restoration cost approach ignores the fundamental uniqueness of natural resources. $\mathrm{CV}$ is able to calculate those additional values without assuming the fungibility of natural resources. Unlike restoration costs, it ensures that the value placed on unique resources can be fully recovered. Also unlike restoration cost, it makes explicit a link between loss and damage payments that is necessary to the efficiency and value recognition roles that nonuse recovery should serve.

Although restoration cost may be useful, it is an imperfect measure of NRDs. DOI agrees, pointing out that "restoration" costs (in the sense of physical restoration) are not able to encompass the full range of losses to the site. CV is the only way of estimating those additional losses. See 56 Fed. Reg. 19,752, 19,759 (1991).

195. See William D. Schulze, Use of Direct Methods for Valuing Natural Resource Damages, in VAluing NATURAL Assets, supra note 25, at 204. Compare this direct inethod with the mdirect methods addressed above. See supra notes 97-101 and accompanying text.

196. See Smith, supra note 32 , at $868-69,875$.

197. See supra note 101 (discussing how CV is more acceptable in this context since it can be compared with techniques such as the travel cost method). 
individuals have little experience with putting prices on noneconomic goods, so the slightest suggestion regarding an appropriate price can bias the results; and there is generally no "behavioral trail" to use as a basis for checking the results of a CV study. Despite these difficulties, CV is the only method available for estimating nonuse values associated with environmental resources.

The questions posed by the typical NRD CV study are designed to determine the "willingness to pay" (WTP) of the person answering the survey. In the area of natural resources, the focus on WTP is incongruous. After all, most natural resources are conceived of as part of the public trust. ${ }^{198}$ Why should citizens be asked how much they are willing to pay for the resources they "own?" The proper value would seem to be the "willingness-toaccept" (WTA), ${ }^{199}$ which is the amount an individual would be willing to accept to give up ownership or a particular quahity of a given resource. As one might expect, however, WTA is generally much higher than WTP since the individual setting the price has both control over the disposition of the good and the wealth reflected by owning it. ${ }^{200}$ It is so much higher in NRD situations, in fact, that DOI and NOAA, along with many economists, reject WTA in an effort to bias CV in a more conservative direction. ${ }^{201}$ The NOAA Panel concurred in this decision. ${ }^{202}$

The decision not to use WTA and its higher values may make pohtical sense, but it is really just that-a pohtical decision. ${ }^{203}$

198. See supra text accompanying notes 89-92.

199. See Schulze, supra note 195, at 209; NOAA Proposed Rules, supra note 8, at 1150,1161 (agreeing that "the conceptually correct measure of lost passive use value for environmental datnage is WTA" because "the government is holding natural resources in trust for the public").

200. See Duncan Kennedy, Cost-Benefit Analysis of Entitlement Problems: A Critique, 33 STAN. L. REV. 387, 401-07 (1981) (describing the disparity between WTP and WTA as the "offer-asking problem").

201. Natural Resource Damage Assessments, 51 Fed. Reg. 27,674, 27,721 (1986); NOAA Proposed Rules, supra note 8 , at 1182 (to be codified at 15 C.F.R. $\S 990.78(\mathrm{~b})(5)(\mathrm{i})(\mathrm{A})(1)) ;$ see Ohio v. United States Dep't of the Interior, 880 F.2d 432, 476 n.82 (D.C. Cir. 1989); Richard C. Bishop \& Thomas A. Heberlein, Measuring Values of Extramarket Goods: Are Indirect Measures Biased?, 61 AM. J. AGRIC. ECON. 926 (1979) (citing results of survey in which WTA was over four times higher than WTP); see also Bishop \& Heberlem, supra note 193, at 283 ("[M]ost-though by no means all-CVM studies have measured only willingness to pay.").

202. NOAA Panel Report, supra note 1, at 4612.

203. Cf. Kennedy, supra note 200, at 444 (concluding that the distribution of 
There is no economic reason that WTA should not be used. After all, it does represent a situation more comparable to the actual state of affairs, im which ownership of (or at least substantial control over) the natural resources is vested in the public, rather than in those who injure those resources. The vesting of that control in the public is, in part, a political affirmation of the psychic value that individuals place in the existence of those resources. It gives the "owners" of the land the power to effectively exclude those who would injure it. Measuring WTP rather than WTA removes that recognition from the damage calculus by permitting industrial polluters to use the land as they wish as long as they are willing to pay for it. By removing this "ownership capital" from the calculus, the WTP measure removes from individuals the impact that they would otherwise have on those who injure a resource. Even as presently constituted, then, CV is likely to significantly underestimiate the true value that individuals place on the destruction of nonuse resources. ${ }^{204}$

The decision to use WTP in most CV studies is representative of decisions made throughout the process of designing a CV study to ensure a conservative bias in the assessment procedure. ${ }^{205} \mathrm{Be}-$ cause of its bias, skeptics of $\mathrm{CV}$ should be particularly willing to accept a WTP-based survey as a basis for assessing nonuse damages, and advocates of $\mathrm{CV}$ and the miportance of nonuse values should press all the harder to have such studies included. Although they do not represent the reality of property rights in the environment, such studies provide the only way of representing the sense of connection between individual and environment, which is

entitlements in cost-benefit analysis is a political decision).

204. This is particularly true in well-conducted CV studies in which individuals are forced to work within their own budgetary constraints. See infra text accompanying notes 234-35. If individuals are not forced to work within their own budgets, they may, among other things, think of public ownership of resources and the accompanying ability to entirely exclude polluters from natural resources as part of their own wealth, thus artificially inflating reported WTPs. See infra text accompanying notes 220-22.

205. See NOAA Panel Report, supra note 1, at 4607,4608 (discussing the need for a conservative design in the $\mathrm{CV}$ process).

Incredibly, in its proposed rules, NOAA felt compelled to further bias the estimates of nonuse losses by requiring in most cases that estimates of WTP be cut in half to provide the actual WTP. See NOAA Proposed Rules, supra note 8, at 1146. The NOAA valuation not only begins with a conservative and conceptually problematic estimate (WTP) but also arbitrarily slashes it in half. At least under the NOAA rules, there should be little fear of excess liability. 
all that is left of that ownership once a resource has been destroyed.

2. The Methodology of $C V$ and Economic Criticisms. Although the heart of CV is the asking of questions, the construction of a well-conducted study begins long before the first encounter between interviewer and interviewee. ${ }^{206}$ The importance of approaching the design of surveys with care and deliberateness is often ignored. As William Schulze points out, CV "encourages the unfortunate tendency in the uninformed to consider themselves experts in survey design." ${ }^{\text {207 }}$ Its simplicity "Inay lull the inexperienced into the behief that a study may be conducted cheaply with hittle developnient effort." ${ }^{208}$ Early surveys that did not coniprehend the full range of complexities necessarily led to flawed results. As Donald McCloskey notes, "Foolish inquiries into motives and foohsh use of hunian informants will produce nonsense. But this is true of foohsh use of any evidence." ${ }^{209}$ Recent work by economists has set forth several requirements that must be followed to ensure that a CV study, and particularly the questions it asks, are well-designed. ${ }^{210}$

206. More detailed discussions of $\mathrm{CV}$ than the brief outline that I have presented here are available. See, e.g., RONALd G. CUMMINGS ET AL., VALUING ENVIRONMENTAL GOODS: AN ASSESSMENT OF THE CONTINGENT VALUATION METHOD (1986); MITCHELL \& CARSON, supra note 16; see also Bishop \& Heberlein, supra note 193, at 281; Freeinan, supra note 25 , at 288-98 (reviewing standards for reliable CV studies and twelve past studies).

207. Schulze, supra note 195 , at 205.

208. Richard T. Carson \& Robert C. Mitchell, Contingent Valuation and the Legal Arena, in VALUING NATURAL AsSETS, supra note 25, at 231, 232.

209. DONALD N. MCCLOSKEY, THE RHETORIC OF ECONOMICS 181 (1985). As McCloskey points out, then, it is not surprising that if you "Ask a Silly Question," see Note, supra note 27 (using that as its title and concluding that the answers are too silly to be used as a basis for environmental liability), your answers will be silly. The solution is not to stop asking questions but to stop asking silly ones.

210. For reviews of the sorts of issues that are necessary to ensure a proper $\mathrm{CV}$ study, see NOAA Panel Report, supra note 1, at 4611-13; Freeman, supra note 25, at 288-89 (listing "six characteristics of a rehable [CV] instrument for estimating nonuse values"); CUMMINGS ET AL., supra note 206, at 231 (listing eleven "reference operating conditions" that, when satisfied, may improve the accuracy of a CV study); see also MITCHELL \& CARSON, supra note 16, at 289-303 (arguing for a "best practice" standard for judging CV reliability and setting forth questions to use as a means of evaluating the quality of a CV study). The proposed NOAA rule also details inany of the requirements proposed by its CV Panel. See NOAA Proposed Rules, supra note 8, at 1182-83 (to be codified at 15 C.F.R. $\S 990.78(\mathrm{~b})(5))$. 
A good CV study, then, begins well before the interviewees are ever questioned. Such an approach ensures that the biases and uncertainties inherent in assessing nonuse values can be minimized. A researcher conducting a CV study can begin with a variety of steps that recent reviews have recommended for the design phase. ${ }^{211}$ A sample population should be identified. The questions themselves inust be drafted, and the interviewer must determine which payment vehicle ${ }^{212}$ and which answer format she will use. ${ }^{213}$ These decisions will alter the form of the questions and may produce biases of one sort or another ${ }^{214}$ To check for those biases, a surveyor should pretest the topic of review both with groups of experts on the resource and in focus groups made up of meinbers of the public. The information that will introduce the questions also should be pretested to ensure that interviewees will understand and accept the premises of the question. ${ }^{215}$ If the questioning is to occur in personal interviews, as many economists have suggested, ${ }^{216}$ the possibility of "interviewer effects" (the desire to impress the questioner by offering a higher willingness to pay) should be examined early in the process.

Once the preliminary work has been completed, field work begins. First, a randomly selected individual is provided with a set of introductory statements that introduce the individual to the resource in question. The mdividual is then asked a painstakingly

211. See, e.g., NOAA Panel Report, supra note 1, at 4611-13 (listing several pre-questioning guidelines to be followed).

212. Will the interviewee, for example, be asked to pay more for consumer goods or more in taxes?

213. Will the question, for example, be open-ended, or will it ask whether the interviewee would be willing to spend a particular amount? The NOAA Panel recommended that the questions be of a referendum or dichotomous choice. (i.e. yes-or-no) format. This format appeared to them to be the nost useful format for conducting a bias-free study. According to the Panel, the format was useful because it corresponded to a real-world choice format and a payment vehicle with which individuals are familiar: that of a referendum placed on a ballot for a vote. See NOAA Panel Report, supra note 1, at 4612 . The proposed rules concur with this recommendation. See NOAA Proposed Rules, supra note 8 , at 1144 .

214. See Bishop \& Heberlem, supra note 193, at 288-91 (discussing the interview bias in five different approaches to $\mathrm{CV}$ studies).

215. See NOAA Panel Report, supra note 1, at 4612.

216. Both mail and telephone interviews also are possible, but they may be less reliable than personal interviews. In addition, they may not offer the flexibility and responsiveness to interviewees that is necessary for the best studies. Id. at 4611 . For this reason, the NOAA proposed rules recommend that personal interviews be conducted whenever possible. See NOAA Proposed Rules, supra note 8, at 1144. 
crafted series of questions regarding how much she would be willing to pay to guarantee the integrity of that resource. After gathering the answers to these questions from an appropriately large number of people, the researchers analyze the data to produce an average value per person. This average value is then multiphed by the number of individuals in the relevant hypothetical market to determine the total economic value behind an environmental resource.

Unfortunately, even well-designed studies cannot completely eliminate uncertainties and bias. As the epigram to this Note suggests, as Part I illustrates in the context of the tort system, and as the discussion of nonuse values points out, any attempt to translate nonuse values into prices will carry with it uncertainty. This has been particularly true for CV. Individuals sinnply are not accustomed to putting prices on nonuse, nonmarket values. When posed with questions from a CV survey, particularly a survey that has not been properly designed, the respondents' inexperience with pricing nonuse values results in poorly considered answers. Forced to place a cash value on a resource, many individuals, if not led through a process of careful consideration, will utilize seat-of-thepants calculations or take inere stabs in the dark to determine what they would be willing to pay. ${ }^{217}$ Alternatively, they may be led in a surprisingly forceful manner by the question format, which they take as a cue regarding the proper approach to value estinnation. ${ }^{218}$ Whatever the ultimate motivation behind the proffered answer, the lack of consideration behind it leads to a number of different problems. ${ }^{219}$

217. See, e.g., David A. Schkade \& John W. Payne, Where Do the Numbers Come From? How People Respond to Contingent Valuation Questions, in Exxon Symposium, supra note 22 , at $271,275-76$.

218. See, e.g., William H. Desvousges et al., Measuring Natural Resource Damages with Contingent Valuation: Tests of Validity and Reliability, in Exxon Symposium, supra note 22, at 92, 114 (noting that, when an initial bid is provided to interviewees, they "may agree to pay the offered bid because their preference for the commodity is ill-defined and because the bid provides a cue about acceptable values"). Differences in WTP responses, of course, will change the ultimate outcome of the study. See Walter J. Mead, Review and Analysis of State-of-the-Art Contingent Valuation Studies, in Exxon Symposium, supra note 22, at 305,326 (noting that different approaches to survey design "lead to substantially different estimates of the same resource value").

219. Time for consideration is, in fact, one way that researchers can try to minimize upward estimation error. See, e.g., Dale Whittington et al., Giving Respondents Time to Think in Contingent Valuation Studies: A Developing Country Application, 22 J. ENVTL. ECON. \& MGMT. 205, 222 (1992) (noting that WTP fell for those individuals who were 
First; individuals do not do a good job of budgeting. Only rarely do individuals answer CV questions after considering what other spending they wonld be willing to forgo in return for spending on the value presented in the CV questions. As a result, the real willingness to pay is generally less than that reported. ${ }^{220}$ In addition, individuals rarely consider other deinands that inight coinpete for a similar allocation of resources. A person might say that she wonld be willing to pay two dollars to protect a whooping crane, but she would probably not give that much for every endangered species and all the additional environmental concerns seeking contributions. Eventually, the WTP per cause would have to be revised downward. ${ }^{221}$ In the absence of the careful analysis and questioning that should characterize a careful study, the result of these failures to consider budgets means that the average reported willingness to pay is generally higher than if individuals were forced to make real trade-offs. ${ }^{22}$

A high reported measure of WTP leads rapidly to extreme results-especially when the scope of the market in a CV study is national. Errors and variations in WTP results are multiplied by the nnmber of households in a survey's market, so that a one dollar change in each household's contribution may translate into an additional $\$ 100$ million that the nation is willing to pay to avoid the loss. ${ }^{223}$ Although the resulting large estimates for nonuse values are not per se incorrect, intuition causes one to recoil from an aggregated willingness to pay of $\$ 10$ billion for a few days worth of sliglitly better viewing in the winter at the Grand Canyon. ${ }^{224}$ One imiglit cloose to limit the extent of the market, but

given time to think but declining to extend conclusions to developed economies without further study).

220. See NOAA Panel Report, supra note 1, at 4605 (discussing the absence of a meaningful budget constraint).

221. See id. at 4604-05 (addressing the "implausibility of responses"); Mead, supra note 218, at 317 (extrapolating from a \$130-per-species WTP for the whooping crane and arguing that, if those numbers held, the total WTP per household for the over 500 endangered species in the U.S. would be over $\$ 60,000$-"clearly an impossible result").

222. For a methodology and survey desigu that seems to counteract some of these difficulties, see Michael A. Kemp \& Christopher Maxwell, Exploring a Budget Context for Contingent Valuation Estimates, in Exxon Symposium, supra note 22, at 217 (discussing the "disaggregation" method). They report that the disaggregation method resulted in significantly lower WTP amounts than did a simgle focus question method. Id. at 232 .

223. See Note, supra note 27, at 1993 n.84 (calculating the impact of certain changes given the potentially large market size).

224. See, e.g., Mead, supra note 218 , at 311. 
even that decision is weighted with pohtical and legal considerations. ${ }^{225}$

Critics also point out that $\mathrm{CV}$ is subject to "embedding problems," which occur when imdividuals place nearly identical values on what seem to be very different levels of environmental loss. ${ }^{226}$ For example, individuals might be willing to pay the same amount to save 200,000 birds as to save $2000 .{ }^{227}$ Rather than measuring a rational willingness to pay, economists argue, the individual imterviewee is merely expressing a general willingness to pay for all environmental resources and perhaps simiply a willingness to pay for what is perceived as "a good cause."228 Critics back this charge by noting that many bids offered by individuals are in amounts like ten or fifty dollars, which are very similar to those traditionally given to charities. 229

For several reasons, this effect is of major concern for $\mathrm{CV} \cdot{ }^{230}$ First, it seems to indicate that the value being ineasured in these studies is not the value that $\mathrm{CV}$ intends to ineasure. CV should measure not how much people think a certain charity is

225. See NOAA Panel Report, supra note 1, at 4605; Smith, supra note 14, at 21 (recognizing the problem of the geographical extent of the market and tracing fundamental differences in studies to differences in the size of the market). To extend the conservative bias that began with choosing WTP over WTA, it might be useful to make a legal decision to limit the market size to individuals within the scope of the trustee's control. A state trustee, for example, would be able to recover only for losses in that state.

Although limiting market size would ignore the lost nonuse values of those outside the state, practical considerations may justify such a himitation. For example, maimtaining a link between the trustee seeking to recover losses and the individuals from whom the loss derives ensures that each sovereign is able to govern its own natural resource values. Furthermore, the loss in values is hikely to be increasingly smaller as one moves away from the site of the loss. See NOAA Panel Report, supra note 1, at 4605 (discussing the limits on market size in one study as based on an expectation of diminishing reported values as well as on sovereignty grounds). Limiting the extent of the market to comply with both the borders of the trustee and the political and intuitive notions of those who are most affected by NRDs may be a conservative yet reasonable decision in the context of calculating total losses.

226. See Desvousges et al., supra note 218, at 113; Kahneman \& Knetsch, supra note 26, at 58-59; Schkade \& Payne, supra note -217, at 289. These identical values can be either positive and of a "charitable" amount, say $\$ 10$ or $\$ 20$, or they may be zero-a decision not to give at all. See NOAA Panel Report, supra note 1, at 4605 .

227. See Desvousges et al., supra note 218, at .113.

228. See, e.g., Freeman, supra note 25, at 297 (suspecting that at least some CV studies capture "a general sentiment for environmental protection"); Kahneman \& Knetsch, supra note 26, at 69.

229. See NOAA Panel Report, supra note 1 , at 4605.

230. The problem is "[p]erhaps the most important internal argument against the rehability of the CV approach." Id. at 4607. 
worth but how much a given environmental good is worth. Second, even if these questions measure something more resource-specific than charitable giving, there is a fear that they reveal that the decisionmaking process underlying these nonuse values fails to follow the traditional view of rational economic decisionmaking. The absence of a "rational" approach casts doubt on the nature of the goods being measured and suggests that they may have no place in economic analysis.

Finally, economists have criticized CV by arguing that what it attempts to measure-existence value-seems to depend on one's knowledge about a given resource. This realization is disturbing to some commentators, who argue that a value either should or should not exist and that making value depend on information leads to perverse imcentives that might encourage the hiding of environmental losses. ${ }^{231}$

Given the complexities of good design and administration, it is not surprising that such criticisms have been targeted at CV. In their calls for the complete exclusion of $\mathrm{CV}$, and therefore of nonuse values, however, the critics have gone too far. Cautious design and administration such as that outhned above can solve many of CV's problems, makmg consideration better than elimination. ${ }^{232}$ As long as the questions being asked are contained within a well-constructed survey, the results will provide useful information. As the court in Ohio noted, "[t]he simple and obvious safeguard agaimst overstatement [of willingness to pay] ... is more sophisticated questioning."233

The first step to more sophisticated questions is following the procedures necessary to good design before asking the questions. For example, the concern over the lack of budget context in most $\mathrm{CV}$ answers might be avoided by bringing budget constraints to the attention of the imterviewee through the question format. One possible way to do so is via a "disaggregation" method like that

231. See Milgrom, supra note 30, at 419, 423 (arguing that values must not depend on knowledge but on facts of resource loss).

232. See NOAA Panel Report, supra note 1, at 4608-09 (listing guidelines necessary to a well-conducted CV study); Department of Interior Natural Resource Damage Assessments, 58 Fed. Reg. 39,328, 39,351 (1993) (noting that a well-desigued survey can alleviate many of the criticisms directed against the use of CV); NOAA Proposed Rules, supra note 8, at 1156-64 (responding to criticisms of $\mathrm{CV}$ by arguing that well-designed studies can overcome most problems).

233. Ohio v. United States Dep't of the Interior, 880 F.2d 432, 478 (D.C. Cir. 1989). 
discussed by Michael Kemp and Christopher Maxwell at the Exxon Symposium. ${ }^{234}$ Under this method, the survey begins by seeking the value that individuals would contribute yearly to a broad range of charitable needs. By narrowing from that context, nore economically and intuitively satisfying results might be derived. ${ }^{235}$

The inore realistic average WTP annount that will result from careful survey design will moot a variety of other criticisms of CV. For example, if the average WTP in the study is valid (and not excessively high on an individual level), then the aggregation of the value over the entire market should be valid as well. ${ }^{236}$ More careful surveys also will go far toward solving the dilemma of einbedding by ensuring that individuals are forced to take their full range of donative options-and their budget constraint-into account. Rather than report a generic amount appropriate for donation to a charity, the individual would be forced to consider the underlying rationality of his or her decision, which would presumably lead to a decrease in the willingness to donate to the protection of the resource. Such a falling off of total WTP is one mdicator that individuals are behaving in an economically rational manner. ${ }^{237}$

To the extent that the embedding effect is not entirely eliminated by more careful questioning, it may simply reflect a conscious or subconscious value that is event-rather than extent-based. ${ }^{238}$ Rather than provide a logical and rational sliding scale corresponding to different levels of loss, one might expect that individuals holding an intrinsic or altruistic existence value would provide a single intuitively "right" price for its loss. That this price would correspond to that given to charities is not surprising; it simply reveals the inherent difficulty that individuals

234. See Kemp \& Maxwell, supra note 222, at 232. But see NOAA Proposed Rules, supra note 8 , at 1160 (appearing to reject this "top-down" approach).

235. See Kemp \& Maxwell, supra note 222 , at 232.

236. For a discussion of the proper scope of a market, see supra note 225 and accompanying text.

237. This conclusion comports with the assumption made by economists, see NOAA Panel Report, supra note 1 , at 4604 , that individuals will act as rationally with respect to any given public good as with any private, rival good.

238. See supra subsection $\mathrm{II}(\mathrm{B})(1)$ (describing the nature of intrinsic existence values and discussing how they do not fit into traditional economic notions of rationality); $c f$. Smith, supra note 14, at 15 (noting that, if individuals demand soine minimal level of resource production, the einbedding effect is not as counterintuitive). 
have in valuing nonmarket goods. One of the few familiar inechanisins for nonmarket "valuation" is, after all, charitable giving. ${ }^{239}$ When David Schkade and John Payne accuse individuals of not thinking "as rational economic actors calculating Hicksian coinpensating variation functions," 240 they are probably right, at least with respect to the extent of those values that are not easily nionetizable. That soine aspect of the value reported by $C V$ is not economically rational does not niean, however, that those values cannot be considered as part of the hability systein. A similar valuation occurs in tort law, yet the uncertain and arguably irrational nature of the award system has not led to its elimination.

Finally, the criticisin that existence interests are not real because they can "spring up" when an individual hears about a natural resource should not prevent thein fron being integrated into environmental liability. The notion of values "springing up" is not so impossible in our legal system. In many instances, we only consider placing a "value" on goods once they are threatened or taken fronı us. It may be, for example, only after a good is placed into the market stream that it takes on value. And in one study of pain and suffering cases, sonie $70 \%$ of the plaintiffs surveyed did not realize before the trial that they could recover for pain and suffering. ${ }^{241}$ Is it so surprising that the same is true for the value some individuals place on their association with natural places? As Rolston noted, "Expect wildland decisions to awaken previously latent and newly emerging values. ... We never umss the water until the well runs dry. We learn what is at stake only when we learn that it is at stake. We awaken to goods when their opposites threaten . . .."242

239. Even in the charitable context, however, it is difficult to consider one's level of donation a proper estimate of the "value" that one places on the charitable purpose. Only when put into the most crude market terms is that donation equivalent to the level of feeling for the charity. Cf. Radin, supra note 31, at 1859-63 (discussing the rhetoric of universal commodification and how it treats everything "equivalent to a sum of money"); Radin, supra note 29 , at $57,65-66$ (discussing the commensurability message broadcast by market rhetoric). Similarly, the extent of the value that we place on environmental goods cannot be fully captured by this reported amount.

240. David A. Schkade \& John W. Payne, Where Do the Numbers Come From? How People Respond to Contingent Valuation Questions, in CONTINGENT VALUATION: A CRITICAL ASSESSMENT tab 6, at 22 (Cambridge Economics, Inc. 1992), edited and reprinted in Exxon Symposium, supra note 22.

241. See O'Connell \& Simon, supra note 40, at 20.

242. Rolston, supra note 88 , at 47 . 
Although CV has its theoretical problems, then, an increasing number of economists nonetheless are coming to the conclusion that $\mathrm{CV}$ can provide valuable information about the level of nonuse values lost in damages to a particular resource. ${ }^{243}$ With careful construction of surveys and thoughtful presentation, the difficulties and biases of the early surveys can be solved, ${ }^{244}$ and with further work in the area, the guidelines can do nothing but improve. In the minds of these researchers, CV does not have irreconcilable difficulties, and, when properly done, can serve as a useful basis for valuing enviroumental losses. ${ }^{245}$

3. Legal Criticisms. Despite the growing evidence that CV can be a useful part of the legal systein, the economic criticisin of $\mathrm{CV}$ has resulted in attacks on its legal appropriateness. Starting froin the premise that CV's results are too uncertain, legal writers have concluded that $\mathrm{CV}$ is too tenuous a basis for legal proof and that its use threatens excessive coinplexity in determining nonuse values. ${ }^{246}$ After all, under the common law, damage calculations

243. Perhaps the most telling confirmation of the utility of CV is the report of the NOAA Panel, which categorically rejected assertions that "there can be no useful information content to CV results." NOAA Panel Report, supra note 1, at 4610. Although establishing what it considered to be "stringent guidelines" for the developinent, conduct, and presentation of $\mathrm{CV}$ studies, the Panel also noted that studies that complied with those guidelines could "convey useful information" and "produce estimates rehable enough to be the starting point of a judicial process of damage assessment." Id. Although those results would necessarily remain subject to the traditional review of evidence by judge and jury, they would provide "an adequately reliable benchmark" to begin that review. Id. at 4611 . DOI has adopted a similar perspective, noting that it "beheves that a well-designed CVM survey can satisfy many of the reference operating conditions" necessary to ensure its reliability. Natural Resource Damage Assessments, 58 Fed. Reg. 39,328, 39,351 (1993). NOAA also agrees. See NOAA Proposed Rules, supra note 8 , at 1156 (" $\mathrm{CV}$ is a valid, proven teclinique when properly structured and professionally applied, and as such is an acceptable method for use by natural resource trustees.").

244. See MTTCHELl \& CARSON, supra note 16, at 231-59 (arguing that CV works in primciple and implicitly asserting that it will meet necessary standards to survive court challenges); Smith, supra note 32, at 876 ("[T]he growing body of comparative evaluations (using choice- and survey-based methods to estimate the values of amenities), field experiments, and uitinately the $\$ 1$ billion-a-year market research industry all confirm that hypothetical questions can be consistent indicators of actual behavior.").

245. This assessment is true notwithstanding the Exxon Symposiun. See Exxon Symposium, supra note 22 (collecting the results of eleven Exxon-funded groups of researchers, most of which rejected the utility of CV).

246. See, e.g., Cicchetti \& Peck, supra note 27; Cross, supra note 27, at 332-33 (arguing that CV "lacks the indicia of reliability necessary for legal use"); Shavell, supra note 27, at 380-81; Note, supra note 27, at 1995 (arguing for a complete ban because the er- 
nust be established with "reasonable certainty."247 For legal opponents of $\mathrm{CV}$, its inherent difficulties in determining noninonetizable values essentially mean that it will never be able to meet legal requirements. ${ }^{248}$ Some authors ${ }^{249}$ also have argued that the unrehability of the surveys and the methodology of CV suggest that it should be madmissible because it fails to comply with the rules of evidence regarding the admissibility of surveys $\mathrm{s}^{250}$ and does not satisfy the rule regarding the adinissibility of expert testiinony. ${ }^{251}$ Although this critical approach must overcome the "rebuttable presumption" that the statutes grant to the trustee, most of the legal commentators that have argued the point see CV as so fundamentally flawed that they are confident that it will never be admitted.

A full response to these legal attacks lias two parts. First, it is important to establish the statutory basis for including nonuse values-both the more traditional option and existence values as well as intrinsic existence values-within the rubric of NRDs. Second, the evidentiary concerns regarding the admissibility and weight of CV must be evaluated to determine whetler judges 'will be able to consider it as they would any other evidence of dainages.

As to the first issue, nonuse values are recoverable under the language of environinental statutes. For CERCLA recovery, the statutory analysis begins at 42 U.S.C. $\$ 9607(f)(1)$, which inandates that "[t]he measure of damages ... sliall not be limited by the

ror is too large); cf. Ohio v. United States Dep't of the Interior, 880 F.2d 432, 476 (D.C. Cir. 1989) (noting and rejecting arguments of CV opponents based on comnion law analysis that CV cannot be considered a permissible basis for recovery).

247. See, e.g., Idaho v. Southern Refrigerated Transp., No. 88-1279, 1991 U.S. Dist. LEXIS 1869, at $* 55$ (D. Idaho Jan. 24, 1991) (ruling that a CV study conducted for unrelated purposes could not serve as a basis for proving existence values). Curiously, however, and importantly for the purposes of this Note, this requirement is not imposed on those attempting to establish nonpecuriary damages. Because setting the level of such damages is essentially a judgment call, estabhishing proof with "reasonable certainty" is essentially impossible. The system recognizes this and grants nonpecuniary tort losses an exemption from this standard. The same should be true for estimates of nonuse losses.

248. See Ciccheti \& Peck, supra note 27; Cross, supra note 27, at 332-33; Shavell, supra note 27, at 380-81; Note, supra note 27, at 1995.

249. See Cicchetti \& Peck, supra note 27; Note, supra note 27.

250. See Fed. R. EVID. 703; MANUAL FOR COMPLeX LITIGATION $\$ 21.483$ (2d ed. 1985).

251. See Daubert v. Merrell Dow Pharmaceuticals, 113 S. Ct. 2786, 2796-97 (1993); Christopherson v. Allied-Signal Corp., 939 F.2d 1106, 1110 (5th Cir. 1991) (en banc) (per curiani); Note, supra note 27, at 1999.

252. See supra note 165 and accompanying text. 
sums which can be used to restore or replace such resources."253 Additional sums recovered can be used to acquire additional resources. ${ }^{254}$

The legislative history of CERCLA suggests that the increment over restoration cost is intended to include the price of the lost use values that occur between damage and restoration. ${ }^{255}$ There is nothing in the recovery provisions regarding the appropriateness or inappropriateness of also including nonuse values in that additional amount or of the possibility that permanent loss of some kind demands inore significant coinpensation. Furthermore, the provision assigning the responsibility for assessinent methodologies is more exphicit. It makes roon for nonuse inclusion, requirmg that the methodologies "take imto consideration factors imcluding, but not limited to ... use value."256 The court in Ohio supports the natural conclusion: "Option and existence values are non-consumptive values compensable under the terins of CERCLA.,"257

Under the OPA, the measure of NRDs is soinewhat narrower, ${ }^{258}$ but room reinains for the assessment of nonuse damages. The legislative history of the OPA, for example, makes clear that the value of sea otters is more than the value of their pelts. ${ }^{259}$ Further, although the OPA focuses attention on the restoration of the resource or the acquisition of an equivalent resource, ${ }^{260}$ it permits the difference in costs between damage and restoration to be assessed. As with CERCLA, if the "replacement" resource does not encoinpass the full range of lost values (as it rarely will ${ }^{261}$ ),

253. 42 U.S.C. § $9607(f)(1)$ (1988).

254. See Ohio v. United States Dep't of the Interior, 880 F.2d 432, 454, (D.C. Cir. 1989) (citing legislative history); see also H.R. CONF. REP. NO. 830, 95th Cong., 1st Sess. 92 (1977), reprinted in 1977 U.S.C.C.A.N. 4424, 4467 (noting that, under the CWA, when the "damaged or destroyed resource is irreplaceable[,] ... the measure of liability is the reasonable cost of acquiring resources to offset the loss").

255. Ohio, 880 F.2d at 454 n.34.

256. 42 U.S.C. \& 9651 (c)(2) (emphasis added).

257. Ohio, 880 F.2d at 476 n.77.

258. See 33 U.S.C. $\S 2706(d)(1)$ (Supp. IV 1992) (outlining the measure of natural resource damages); id. § 2702(b)(2)(A).

259. See S. ReP. No. 94, 101st Cong., 1st Sess. 15 (1990), reprinted in 1990 U.S.C.C.A.N. $722,737$.

260. See 33 U.S.C. \& $2706(d)(1)(A)$.

261. See notes 122 and 194 (discussing and rejecting a restoration-based damage calculation as unable to fully compensate nonuse losses). 
additional costs would be applied to the acquisition of additional resources. ${ }^{262}$

There is, therefore, plenty of statutory room for the inclusion of nonuse values. Since CV is the only explicit means of conducting that assessment, the only reinaining legal barrier addresses the admissibility of and evidentiary weight that should be given to CV.

As slould be the case when nonmonetary values are translated into prices, ${ }^{263}$ the standards governing admissibility of $\mathrm{CV}$ should be relatively lennent. This conclusion is true for several reasons. First, the general rule governing CERCLA and other remedial environmental statutes is that they should be read liberally to ensure that they are implemented in favor of the public. ${ }^{264}$ The court in Ohio, for instance, notes that, although the extent of damage due to losses may be severe, "it is in the mission of CERCLA to assess the public loss." 265 The broad reading, in the eyes of the court, included using a "more expansive survey and correspondingly higher assessment of damages" in a CV study of Texas wlooping cranes. ${ }^{266}$ This approacl, which reflects the remedial imtent of CERCLA, certainly seens to approve of the use of CV methodologies.

Second, the rebuttable presumption will reinforce any attempt by the trustee to admit CV-even if the presumption has been rebutted. The presumption serves as a counter to common law rules requiring "precision" in the proof of dainages, which might otherwise be imported into the evidentiary requirements. ${ }^{267}$ As the Ohio court noted, common law strictures, including the one that bars recovery for speculative injuries, do not apply to CERCLA. ${ }^{268}$

Third, rules of evidence regarding standards of scientific accuracy and overall probativity can be met by a well-executed CV study. The probativity is mdicated by the absence of other means

262. See, e.g., id. $\S 2706(c)(1)(C)$. NOAA's proposed rules agree with this assessment and require inclusion of nonuse values in the measure of compensable damages under the OPA. See NOAA Proposed Rules, supra note 8, at 1151.

263. Witness the nearly nonexistent standards governing what jurors may consider in dehiberating over the level of awards for nonpecuniary injuries. See supra Part I.

264. See, e.g., Idaho v. Hanna Mining Co., 882 F.2d 392, 396 (9th Cir. 1989)

("CERCLA should be given a broad, liberal construction.").

265. Ohio v. United States Dep't of the Interior, 880 F.2d 432, 477 (D.C. Cir. 1989).

266. Id. at n.87.

267. See supra note 247.

268. See Ohio, 880 F.2d at 476. 
of including nonuse values and by the body of literature supporting the usefulness of well-conducted $\mathrm{CV}$ studies. ${ }^{269}$ Given the dramatic increase in the number of $\mathrm{CV}$ studies, the inethodology also can meet the requirement that expert testimony be rehable and relevant. ${ }^{270}$

Admitting CV results as evidence in NRD trials does not end the analysis. As with all other evidence submitted by witnesses, the relative weight given the CV-based evidence is subject to evaluation by the judge. When the survey is not conducted well or when the ainount reported by the survey smiply seems irrationally large, it will be within the prerogative of the judge to determine that the nonuse values should not be priced in precisely the inanner called for by the CV results. Just as past cases and personal experience provide a basis (albeit a weak one) for consistency in awarding dainages for pain and suffering, the judge may use $\mathrm{CV}$ as a basis for determining the level of nonuse values that should be awarded in NRD cases.

4. Practical Concerns. The economic challenges to the use of CV are backed up in the minds of its critics not only by the legal challenges but also by the various practical difficulties associated with its use. For its critics, the most muportant of these difficulties is the uncertainty and ultmiate cost of awards based on these surveys. These critics point to figures suggesting awards regularly aggregating into the billions of dollars for relatively minor enviroumental injuries and argue that such results, ainong other things, seein to "stretch the 'reasonableness standard' to the breaking point" 271 and that the inagnitude and range of the a-

269. See, e.g., Carson \& Mitchell, supra note 208, at 231.

270. The new standard comes from Daubert v. Merrell Dow Pharmaceuticals, 113 S. Ct. 2786 (1993), and its imterpretations of FED. R. EVID. 703. Under Daubert, scientific evidence need no longer be based on practices that are "generally accepted" in the scientific community. The new standard, based firmly im the Federal Rules of Evidence, merely requires that the methodology be rehiable and relevant. $113 \mathrm{~S}$. C. at 2795; see also FED. R. EVID. 403, 703. Even if the "generally accepted" standard still carries some weight, CV would have little problem qualifying. See Carson \& Mitchell, supra note 208, at 231 ("If asked by a judge, an economist as an expert witness for either plaintiff or defendant would have to say that [CV] is now clearly a method that inany experts routinely rely on as a base for their judgments."); NOAA Proposed Rules, supra note 8, $1142-43$ (CV "has become one of the most widely used inethods of nonmarket valuation.").

271. Mead, supra note 218 , at 316. 
wards are "enormous"272 and "contrary to both common sense and current allocations of public resources."273 Although inappropriately large awards can lead to economic inefficiency, it is perhaps the uncertainty associated with the level of awards that most threatens economic plaming and that will generate excessive amounts of litigation. ${ }^{274}$

Several points can be made in response. First, pain and suffering awards are just as uncertain in amount as are awards for environmental injuries. Yet pain and suffering awards have been a part of the legal systein for centuries, and the system nonetheless reInains stable. Second, judicial reviewability of CV evidence provides a check on "runaway" CV studies. Third, carefully designed studies will report realistic dainages-even if those dainages seem excessive. Finally, CV is not and will not be used in every litigated NRD case. Vahd CV studies take time, energy, and money. As the NOAA Panel points out, "[I]n the present state of the art, a reliably conservative CV study should be conducted witlı personal interviews of significant duration and will therefore be relatively costly."275 Although litigants will provide the necessary resources when the stakes are high, ${ }^{276}$ using CV in minor spills with iminiinal nonuse values would be extravagant. The DOI regulations, for exainple, largely reflect these considerations, with divisions between simple-to-conduct, resource-lean type $A$ regulations and coinplex, resource-intensive type B methodologies. ${ }^{277}$ Being a streamlined approach to evaluation, type $A$ inethods will be of the most use when the impact is minor. ${ }^{278}$ Type B processes, on the other land, "would cover 'large or unusually damaging releases." "279 Since minor releases will be more common than major

272. Id. at 324 .

273. Id. at 325 . As is noted above, however, see supra text accompanying note 269 , if an award is "beyond the bounds of common sense," it would be within the capacity of the judge or jury as factfinder or the judge as adjudicator to unilaterally reduce the amount suggested by the CV study. Such adjustment is not uncommon in the case of awards for nonpecuniary losses.

274. Shavell, supra note 27, at 378-81; Note, supra note 27, at 1990-92.

275. NOAA Pauel Report, supra note 1, at 4607.

276. Consider, as an extreme example, the $\$ 3$ million $C V$ study done by the state of Alaska. See Ken Miller, How Much Is a View Worth? Commerce Agency Wants to Know, GANNETT NEwS SERVICE, Feb. 6, 1993, available in LEXIS, Nexis library, GNS file.

277. See supra note 161.

278. See Colorado v. Umited States Dep't of Interior, 880 F.2d 481, 487 (D.C. Cir. 1989) (discussing legislative intent regarding the scope of type A regulations); WARD \& DUFFIELD, supra note 91 , at 157.

279. Colorado, 880 F.2d at 487 (quoting S. REP. No. 848, 96th Cong., 2d Sess. 86 
ones, type A methods will ultimately be the most heavily utilized. In addition, both methods require the cost of assessment to be reasonable in light of the expected recovery, ${ }^{230}$ further discouraging a blunderbuss approach to the use of $\mathrm{CV}$ in estimating nonuse values. ${ }^{281}$

Even some of the harshest critics of CV understand this important aspect of the nature of CV's utility, admitting that it might be useful when the extent of the injury is large, when the damage occurs to unique resources, when individuals are familiar with the damaged resource, and when the damage caimot be repaired over a short period of time-i.e. in precisely those situations in which CV would be nost likely to be used. ${ }^{282}$ In such cases, however, the stakes will be high enough that the parties will invest significantly in making sure that the study is done in the most effective way possible. ${ }^{283}$

(1980)).

280. 56 Fed. Reg. 19,752, 19,754 (1991) (to be codified at 43 C.F.R. pt. 11). Critics might argue that the malleability of CV would permit greedy trustees to conduct a sloppy study in an effort to bump up the expected level of damages. This outcome is unlikely because any attempt to do so would be met with both the skepticism of the court and the absence of the rebuttable presumption that is available only when very detailed regulatious addressing the development and administration of the survey have been followed.

281. One unfortunate practical implication of this approach to the use of CV is that it ignores the intrinsic value that individuals place on completely undisturbed resources that are relatively unreinarkable in size or uniqueness. Over time, and after extended academic and legal considerations of $\mathrm{CV}$, it may be possible to create a schedule of damages based on prior awards that would permit at least some recovery of these nonuse values that will otherwise be shipping through the cracks. The NOAA Panel seemed to have had something like this "scheduling" in mind (although perhaps not as directed toward minor recoveries) when it called on "appropriate federal agencies [to] begin to accumulate standard damage assessments for a range of oil spills." NOAA Panel Report, supra note 1, at 4611. For a scheduling approach to the award of pain and suffering, see Bovbjerg et al., supra note 46 . Such an approach will admittedly be an inperfect conpromise between the reality of intrinsic nonuse values and the reality of NRD recovery, but it would ensure at least some level of recoguition for those rights.

282. See Note, supra note 27 , at 1995-96 (permitting, as a "second-best alternative," the use of $\mathrm{CV}$ in cases of "irreversible, or very long-lasting, adverse impacts to unique, widely-recognized natural resources") (quoting Natural Resource Damage Assessments, 56 Fed. Reg. 19,752, 19,760 (1991) (to be codified at 43 C.F.R. pt. 11)).

283. Charles Cicclietti and Neil Peck therefore jump the gun: they ask a facetious question regarding what economist would invest the necessary time and energy to ensure that a CV study is conducted properly and assume that the answer is "none," Cicchetti \& Peck, supra note 27, at 8, when the reasoned answer is, "any econormist that will be conducting a CV study in a significant, litigated case." 
5. Philosophical Concerns. A final criticism of CV, curiously enough, comes not from those who might have an interest in avoiding the pecumary losses associated with increased damage awards but froin those one inight expect to draw satisfaction from the imposition of damages. According to these environmental ethicists, attempting to fit nonuse values into a systein of economic valuation cheapens the values and the resources from which they derive by forcing thein into the very anthropocentric structure that intrinsic existence values are attempting to escape. ${ }^{284}$ Imposing an econoimic value on a resource, and particularly on that part of the resource represented by its intrinsic worth, is at best a meaningless task $^{285}$ and at worst another step in the fragmentation and econolmic colonization of natural values. ${ }^{286}$ The monetization of nonuse values, and therefore CV itself, "forces the user to be a consumer and compromising pragmatist in a decision context in which he ought to be a citizen, esthete, philosopher, and ethicist."287

This perspective, which argues for the sanctity of certain natural values, has some parallels with the observation by Margaret Jane Radin that certain "goods" in society are kept inalienable for a reason. ${ }^{288}$ For example, according to Radim, one reason to place limits on the ability to sell our bodies-whether in the forn of slavery, prostitution, or "paying" donor organs-is because it is only in an incommensurable state that our concept of the body can play a critical role in our development as individuals and as a society. ${ }^{289}$ As with Rolston's view of intrinsic values, there is a sense that pricing the body would soinehow dimimish its place in society. This perspective also echoes the criticisms that have been

284. See Edwards, supra note 95, at 78 (noting that there "seems to be general agreement with Kelman's view that monetizing environmental values somehow cheapens the resource") (citing Steven Kelman, Cost-Benefit Analysis, REgulation, Jan.-Feb. 1981, at 33, 38-40); Rolston, supra note 88, at $36 \mathrm{n} .11$ (noting that calling those who value mere existence "off-site users" "exactly reverses what those so categorized would say of themselves").

285. See Rolston, supra note 88 , at 38 "'To insist on pricing is to insist on a category mistake . . .."); Sagoff, supra note 3 , at 1410 .

286. See Rolston, supra note 88 , at 33 (Valuation forces individuals "to translate a good which is collective and nonmarket ... into a good which is private and market."); Sagoff, supra note 3, at 1394 (Valuation "makes economic efficiency our only goal."); Sagoff, supra note 4, at 269-70 n.14 (referring to valuation as economic "imperialism").

287. Rolston, supra note 88 , at 34 .

288. See Radin, supra note 31 , at 1855 .

289. Id. at 1907-09. 
directed against awards for pain and suffering that argue that those awards cheapen the enotions involved in individual pain and sorrow. ${ }^{290}$

By isolating at least nonuse values froin the assessinent process, environmental ethicists beheve that we would be better able to celebrate and understand the nature of these values and the resources froin which they are derived. By not condonimg the equivalence of nonuse or nonpecuniary values, we do not risk that they will fall into the trap of commodification. in which everything is available for the right price.

The response to this criticism can only be that the inclusion of nonuse values does inore good than harm. Understanding that good is the topic of the final Part.

\section{The PaIn AND SuFfering of ENVIRONMENTAL Loss AND THE NECESSITY OF CV}

The discussion thus far establishes that $\mathrm{CV}$ can provide a rehable starting point for discussions about nonuse losses in natural resource dainage assessments. It has said inuch less, however, about why those damages, and therefore $\mathrm{CV}$, should have a role in NRD assessinent. This Part reviews the reasons why nonuse values should be included in NRD assessment, using the model of recovery for pain and suffering as a template for the introduction of CV into the legal system.

\section{A. The Identity of Pain and Suffering and Nonuse Values}

Perhaps one of the inost persuasive replies to the critics of $\mathrm{CV}$ is simply to point a finger in the direction of tort recovery. Pain and suffering and CV are subject to many of the saine criticisins, yet the former is a sizable part of the tort hability system. Since the problems witlı including nonuse values are neither qualitatively nor quantitatively different from those directed at the use of pain and suffering, there is no practical reason why CV should not play a significant role in the assessinent of nonuse values. The rationales behind retaining pain and suffering awards further contribute to the conviction that nonuse values, througl1 $\mathrm{CV}$, should be part of environmental hability dainages. ${ }^{291}$

290. See supra notes 74-76 and accompanying text.

291. Christopher Stone briefly drew this parallel over twenty years ago and concluded, 
The first important parallel between CV and pain and suffering is that the two measurement systems face the saine mechanical difficulties. Each measures the gap between full compensation and compensation for monetary loss. Nonuse value is the difference between the total environmental loss at a site and the measure of use values, ${ }^{292}$ whereas pain and suffering is the difference between the total recovery and the monetary losses like medical expenses and lost wages. ${ }^{293}$ Distant froin physical or market anchors, both types of value face the imprecisions and frustrations that necessarily result when "intangible losses have to be evaluated in monetary terins."294 Both value systems are imcominensurable with economic analysis, requiring the legal system to approach the problem of their valuation in inuch the same way. ${ }^{295}$ As Randall Bovbjerg and his colleagues have noted, "The problein with noneconoumc dainages is, im sum, not that they are inappropriate or unreal, but rather that they are extrenely difficult to consistently inonetize in the absence of quantitative standards."296 That absence does not mean that they should be eliminated froin consideration. As Stanley Ingber lamented, although the extent of loss is uncertain, "the existence of such economic loss is virtually assured. To refuse any coinpensation because of the danger of error in determining an anount is to guarantee that all such costs are absorbed by the plaintiff rather than the defendant." ${ }^{297}$

as this Note does, that the presence of uncertainties in valuation does not justify a complete bar on the assessment of nonuse values. See Stone, supra note 125, at 478-79. The benefits of that inclusion are simply too great.

292. See 56 Fed. Reg. 19,752, 19,760 (1991) (to be codified at 43 C.F.R. pt. 11).

293. See Viscusi, supra note 37, at 205.

294. NOAA Panel Report, supra note 1, at 4611.

295. Soune might argue that pain and suffering valuation is different than interviewecs' valuation of nonuse values since "jurors at least have some frame of reference in their own general experience to appreciate what the plaintiff has lost." Turpin v. Sortini, 643 P.2d 954, 964 (Cal. 1982). Presumably, that reference is their own experience with pain. There is no reason to think, however, that individuals have any more experience with pain or anguish than they do with environmental loss; in fact, their experience with the latter might be greater than with the former.

Another claim might be that juror exposure to the tort system through the news and other experiences has given them a sense of "appropriate" awards. Although possible, it would be true only because the system has been in place for years. In the beginning, pain and suffering relied merely on individual perceptions of appropriate damages. There was no systemic ineltdown when pain and suffering, emotional distress, or any other nonpecuniary loss was introduced into the hability system. The system would handle nonuse assessment similarly well.

296. Bovbjerg et al., supra note 46 , at 936 .

297. Ingber, supra note 47 , at 780 . Ingber actually was talking about difficult-to-value 
Faced with a lack of a behavioral trail that reveals individual preferences, both types of values inust turn to the conversationgathering inode 298 as a ineans of directly determining loss values. Whether it be in a jury room or at an interview table, the process of determining nonmarket losses is based on the same premise-that the only way to determine thein is to reflect on one's own value systein and then attenipt to place a price on the intrinsic values that reside there. Contingent valuation's methodology imposes a inore cautious scientific structure on the valuation progress than does a jury dehberation; a jury verdict on pain and suffering amounts to nothing inore than the end result of an extremely unsophisticated, extreniely uncontrolled CV process. $^{299}$ If put through the academic and economic rigors to which $\mathrm{CV}$ has been subjected, juries would likely fare no better, and likely inuch worse, than CV. In all likelihood, jury verdicts are less fact-based and more prone to subjective appeals and biases than any wellconducted CV study.

The mechanical and practical difficulties in measuring nonniarket values, at least in the case of pain and suffering, are outweighed by the economic and philosophical value gained fron including these values within the tort systent. These rationales supporting the role of pain and suffering in the tort systein, not surprisingly, also apply to the inclusion of nonuse values in NRD assessnient.

pecuniary losses in this quotation-he believed that nonuse values should be excluded from consideration because of the "double cost" problem that arises froin compensating individuals who cannot be made whole agam. See id. Even if his argument is valid for pain and suffering, it does not establish that nonuse values should not be considered in environmental compensation programs. In fact, it shows the opposite. For nonuse values, the "double counting" argument does not apply since the environment, or perhaps we should say the public good that is environmental preservation, is better off, in that the additional recovery is translated into additional purchases of environmental goods. Even if there is a little bit of overcompensation, there is no duplication of the defendant's loss because the value of the additional resource damages recovered will go to purchase of unore goods.

298. See Snith, supra note 32, at 867-68.

299. In that $\mathrm{CV}$ attempts to impose some rational order on this process, it actually has more structural potential for achieving a valid result than does the jury analysis of pain and suffering. 
B. Economic Justifications Supporting a Role for Nonuse Values in Liability Awards

The simple fact that nonmarket values have a positive magnitude counsels im favor of mcluding them in hability assessment. Economically, ignoring positive values leads to inefficiencies. ${ }^{300}$ Unless imdividuals are required to pay for the full measure of harms they impose on society, they will not have an incentive to act efficiently. ${ }^{301}$ As the court im Ohio noted im the context of environmental losses, "[o]ption and existence values may represent 'passive' use, but they nonetheless reflect utility derived by humans from a resource, and thus, prima facie, ought to be included in a damage assessment."302

Additional rationales favor the inclusion of nonuse environmental values. First, they are nonconsumptive "uses." As such, they are public goods, ${ }^{303}$ and government must act to ensure that they are fairly represented in the legal and policymaking processes. ${ }^{304}$ In addition, failing to include nonuse values favors the present, to the exclusion of future, generations. Because use values are almost exclusively targeted at present use, those future generations are left out of resource allocation. Including option values in NRD assessment provides one way for us to explicitly include future users in our decisions about resource allocation and hability.

300. "Furthermore, when it is recognized that even small per capita nonuse values may be very large in the aggregate if they are held by a substantial fraction of the population, there is a real possibility that ignoring nonuse values could result in serious misallocation of resources." Freeman, supra note 25, at 297.

301. This is the problein of "externalities," which occurs, in economic terms, when producers do not see the same costs to their activities as those activities actually impose on others. Although they may be profiting at a given level of production, then, or acting with a given level of caution, that level is not efficient for society as a whole. See generally TIETENBERG, supra note 90, at $45-47$ (introducing extemalities); WARD \& DUFFIELD, supra note 91, at 225-28 (same). The solution-to "internalize" the externality-requires that those suffering the uninternalized costs determine how to force the producer/actor to take them into account. See $i d$. at 226-28. This result can be accomplished through taxation, standard setting, or (in the case of NRDs) the liability system. See Stone, supra note 125, at 474-76 (recognizing the beneficial effect on economic efficiency of recognizing nonuse* values, albeit values based in the individual resource, and not in inankind); NOAA Proposed Rules, supra note 8, at 1151 (recognizing a similar effect in justifying the inclusion of nonuse values in NRD assessment).

302. Ohio v. Umited States Dep't of the Interior, 880 F.2d 432, 464 (D.C. Cir. 1989).

303. See supra note 118 (discussing the nature of nonuse values as public goods).

304. See supra note 92 (discussing the reasons why the government inust step in to ensure proper allocation of public goods). 
Any apparent "irrationality" in resource valuation need not preclude recovery of nonuse values. In pain and suffering cases, for example, individuals do not have well-articulated values for pam and suffering losses. Nonetheless, the process of translating those losses from unmonetizable feelings into cash is one with which we have become familiar and that we trust to provide results that do not disrupt our intuitions about how costs change with injuries. Even if those results are not precisely logical or ordered, they do represent a level of stability sufficient to permit a continuing role for paim and suffering. They should do the same for nonuse values.

\section{Nonmarket Damages and the Importance of Affirmation}

As this Note has poimted out, nonmarket values im both tort and environmental law contain significant components that are incommensurable with a system of economic valuation. ${ }^{305}$ This aspect of nonmarket values is seen in practice in the difficulty that individuals (and economists and the legal system) have in estmiating the value of these losses. ${ }^{306}$ Cass Sunstein points out that the confusion and uncertainty inherent in the deterinination of damage awards is in fact a clash between valuation regimes-an "incoinmensurability" on the part of a regime that sees values as a sort of perfect hierarchy not subject to the boiling down that occurs all the time in the economic regime. ${ }^{307}$ This complexity and the occasional refusal to participate reflects not "sentimentahity or simple confusion" but a true alternative value judgment that does not admit an economic valuation. ${ }^{308}$

If the values lost are incommensurable with the money received, why should we award damages at all? We should award dainages because ignoring nonuse values in the assessment of NRDs may have a philosophical and psychological impact as well as an economic one. In a system in which the currency that conveys value is inoney, not only does the exclusion of nonuse values

305. See, e.g., supra subsection II(B)(1) (discussing the nature of existence values).

306. In addition to the examples that permeate the discussion above, individuals may register this inability by giving a "protest bid" response to a CV question. See Rolston, supra note 88, at 34; Sunstein, supra note 29 , at 36-37. The unwillingness to provide "realistic" bids represents this incommensurabihty in our environmental values.

307. See Sunstein, supra note 29 , at 38 .

308. Id. 
assign them an economic value of $z^{2} \mathrm{ro}^{309}$ but it also indicates that the legal and pohtical system fails to recognize them at all. Especially in a society as litigious as the United States, the absence of nonuse values from the legal decisionmaking and compensation process unay diminish them in the mind of society, thereby reducing the overall value that we derive from the environment. Awarding trustees of natural resources damages for the full range of nonuse values recognizes the importance that individuals place on the preservation of pristme areas. ${ }^{310}$ It affirms that those values-and those places-are an important part of our national psyclie. The award also provides, at least at some level, a distraction from the loss itself in the form of additional environinental protection through the purchase or restoration of another natural resource.

In addition to acknowledging loss, pain and suffering awards affirm the importance of every imdividual in society, regardless of their earning potential, and guarantee that at least part of the tort liability system is based on individuals as people, not as wage earners. ${ }^{311}$ In a similar way, nonuse value awards affirm the importance of every part of the environment, not just those that liave "market potential." Relying exclusively on use values reduces the value of environmental goods to their inarket potential and ignores the full range of values that are held in those resources. Even if the magnitude of nonuse losses is not easily established, assessing those losses ensures that our society is compensated for the full value of losses to environments that are not subject to developinent, not subject to extractive uses (such as fishing or lumbering), or inerely too remote for recreational use. The very point of recognizing nonuse values is that every environment-even those not represented by market prices-is of value to us and our children.

309. See Freeman, supra note 25 , at $6,19$.

310. At least one economist has explicitly recognized this ethical content of nonuse valuation. See Raymond J. Kopp, Environmental Economics: Not Dead but Thriving, RESOURCES, Spring 1993, at 8; see also Ingber, supra note 47, at 781 ("[B]ecause money is highly valued in our society, we use it to measure and recognize the worth of both tangible and intangible items. If society is to signify its commitment to the support of psychic well-being, damages for intangible injuries must be permitted.") (citation omitted); Levit, supra note 39 , at $188-89$ ("Because money is the measure of value in a market economy, the refusal to compensate an injury is a direct message about the worth of the imjury; compensation legitimizes the interests and emotions it rewards.").

311. See supra text accompanying notes 85-87. 
These points begin to suggest a resolution of the philosophical concerns raised by Steven Kelman, Holmes Rolston, and others regarding the risks of "cheapening" natural values by forcing them into an economic valuation regime. ${ }^{312}$ Under a systein in which CV merely attempts to establish some correlation between nonuse values and inoney, and in which compensation is not necessarily viewed as commensurable with lost values, those values retain the core of their identity-their incommensurability. This incommensurability camiot be resolved by $\mathrm{CV}$ because $\mathrm{CV}$ is not and probably never can be a perfect translator between environmental values and economic ones. Even for well-conducted CV studies, the imperfect translation manifests itself in residual uncertainties and doubts. Those uncertamties are more than a manifestation of incommensurability, however; they actually help us to inaintain that incommensurability-that barrier between the two types of values-and in doing so, those uncertainties buffer moral convictions froin the "economic imperialism"313 that ethicists fear. This value of uncertainty also is present in the complexities and uncertainties of tort law. As Margaret Jane Radin appropriately notes, we may want to be careful about making the relationship between mjury and recovery too clear through, say, schedules of loss. ${ }^{314}$ By making the systein work inore sinoothly, we actually encourage a commensuration between previously incommensurable values and thereby remove some of the value froin the inystery of those einotions. As long as the processes for valuing these losses remain "black boxes," we need not force ourselves to understand how the values on opposite ends are coininensurable, and we need not fear that they will actually so becoine..$^{315}$

In a system in which the incommensurable nature of the values we are trying to estimiate is protected through the very difficulty of translation-through the "black boxes" of pain and suffer-

312. See supra subsection III(B)(5).

313. See supra note 286.

314. See Radin, supra note 29 , at 83.

315. There is one valid fear, however: our environmental behefs may not be as resilient in their incommensurability as are our beliefs regarding pain and suffering. See Sunstein, supra note 29, at 23-24 (noting that our once-inviolate views regarding the environment have already taken on economic terminology). Under such a perspective, any slippage in our unwillingness to enter into pricing activities for intrinsic environmental values threatens a switch to commensurability. This shippage may not be as likely in the context of pain and suffering awards if, as Radin believes, our view of pain and suffering is quite resilient. See generally Radin, supra note 29. 
ing verdicts or $\mathrm{CV}$-it makes sense to at least play along with the valuation game. After all, the need is there. Ignoring the nonuse values, for example, permits far too great a loss in the world of environmental recovery. As long as the values that we cherish are not inherently convertible into cash, trying to make that conversion will be disturbing. But as long as our legal system-and our businesses-think of damages solely in monetary terins, recognition of those mjuries will not truly occur until we can place a value on them. ${ }^{316}$ Contingent valuation does just that.

\section{CONCLUSION}

The various economic, philosophical, and legal arguments posed against the vahdity of $\mathrm{CV}$ will continue for some time to coine. Despite uncertainties in CV inethodologies, however, agencies and courts should permit $\mathrm{CV}$ to serve as one piece of evidence in the effort to properly assess the value of natural resource damages. The consistently positive response to $\mathrm{CV}$ studies and our own experience indicate that many of us do place a value on the mere existence of natural places and organisins. The difficulties involved in translating this value into inonetary terins do not justify the complete rejection of a method that has the potential for reporting useful information. Although a significant body of criticism regarding the mechanics of $\mathrm{CV}$ methodology has been developed, caution in design and admimistration can resolve inost of the difficulties recognized by those critics.

To the extent that criticisins of even well-conducted CV studies remain, they go not so much to the vahdity of the method as to questions regarding the appropriateness of niserting these sorts of values into the hitigation and policymaking processes. The decision, then, is not a technical decision, but a political, moral, and legal one: are existence values the sorts of things that we consider an important part of natural resource damage recovery?

As this Note has argued, nonuse values should be a part of NRD assessinent. Just as in the award of damages for nonpecuniary losses, the econoumic and moral argunients in favor of including nonuse values overwhelm any residual concerns regarding certainty or excessive fines. In at least one area of the law, the

316. On the necessity of reducing values that need to be considered in policy analysis to monetary terms, see infra text accompanying note 318 . 
pohitical, moral, and legal judgments have been resolved in favor of including nonmarket values. Reaching a similar resolution in the case of environmental hability is both possible and necessary.

In recognizing that necessity, this Note is a detailed investigation into one example of the imsight offered by Cass Sunstein in a forthcoming paper. ${ }^{317}$ In it, he suggests that incominensurability crops up as a driving force in inany areas of the law. Although he acknowledges that we must not try to force our society to work with only one system of valuation, that acknowledgment is not

fatal to the view that law and public policy sometimes ought to be founded on modes of valuation that are umitary. It is possible to think that under ideal conditions, the best system of valuation is diverse and plural, but that in light of the weaknesses of human institutions and the constant prospect of bias and arbitrariness, public choices should assume a single mode as the best way of promoting all of the relevant goods. This is not a question that can be answered a priori or in the abstract. It is possible to beheve, for example, that government officials should value relevant goods along ... a single metric as a way of promoting the best form of government regulation, all things considered. But it is important for those who take this position to understand that it is best defended as a means of overcoming certain institutional obstacles, and not as a fully adequate understanding of the relevant problems.

All this leaves much uncertainty. ${ }^{318}$

The approach to CV advocated by this Note-and CV itself-is not perfect economically, ethically, pohtically, or legally. That imperfection, however, is largely the result of a clash between two different ways of looking at the world. In one, cash is the common denominator. In the other, ethics reject cominon denominators as a vehicle by which values are compromised. We are already familiar with the resulting clash in a variety of fields, ${ }^{319}$ one of which-pain and suffering-is presented here,

317. See Sunstein, supra note 29 , at 49.

318. Id. (citations omitted). When Holmes Rolston parodies politicians and policymakers by arguing that "[t]hey believe that one sure route into human caring is by pricing ... in matters of resource use," he recognizes this very point. Rolston, supra note 88, at 24. He disagrees, however, with its necessity, and, were this a perfect world, I might agree with him.

319. See Sunstein, supra note 29 , at 26-48 (discussing the manifestation of this conflict im nine different areas). 
and we also already know that the practical manifestation of the conflict is uncertainty and dissatisfaction. ${ }^{320}$ As with those other areas, however, the best option is not rejection of one perspective or another but an effort to accommodate both in the most reliable way possible. In the regime of nonuse values, that way is contingent valuation.

320. See id. 